\title{
Differences in crop selection, resource constraints, and crop use values among female- and male- headed smallholder households in Kenya, Tanzania, and Uganda
}

SPECIAL ISSUE: MORE THAN VALUES IN THE FOOD SYSTEM

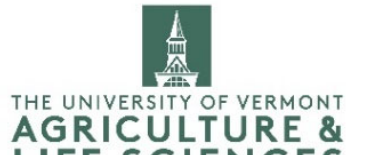
AGRICULTURE \& LIFE SCIENCES

\author{
Travis W. Reynolds a * \\ University of Vermont \\ Daniel Tobin ${ }^{b}$ \\ University of Vermont
}

\author{
Gloria Otieno ${ }^{c}$ \\ Bioversity International
}

\author{
Aidan (Conor) McCracken ${ }^{\mathrm{d}}$ \\ University of Vermont \\ Junru (June) Guo e \\ University of Vermont
}

Submitted October 4, 2019 / Revised December 19, 2019, and February 28 and April 10, 2020 /

Accepted April 13, 2020 / Published online July 22, 2020 / Updated funding disclosure September 1, 2020

Citation: Reynolds, T. W., Tobin, D., Otieno, G., McCracken, A., \& Guo, J. (2020). Differences in crop selection, resource constraints, and crop use values among female- and male-headed smallholder households in Kenya, Tanzania, and Uganda. Journal of Agriculture, Food Systems, and Community Development, 9(4), 65-92. https://doi.org/10.5304/jafscd.2020.094.011

Copyright (C) 2020 by the Authors. Published by the Lyson Center for Civic Agriculture and Food Systems. Open access under CC-BY license.

\begin{abstract}
A growing body of research suggests female- and male-headed households in low- and middleincome countries differ in terms of crop choices,

a* Corresponding author: Travis W. Reynolds, Department of Community Development and Applied Economics, University of Vermont (UVM); Morrill Hall; Burlington, Vermont 05405 USA; +1-802-656-8115; twreynol@,uvm.edu

b Daniel Tobin, Department of Community Development and Applied Economics, UVM; Daniel.Tobin@uvm.edu

c Gloria Otieno, Associate Scientist, Genetic Resources and Food Security Policy, Bioversity International, Kampala, Uganda; g.otieno@,cgiar.org

d Aidan (Conor) McCracken, Department of Community Development and Applied Economics, UVM.

e Junru (June) Guo, Department of Community Development and Applied Economics, UVM.
\end{abstract}

access to resources for growing different crops, and values placed on crops for home consumption versus market sale. To better understand relationships between gender of the household head, household resources, individual values, and crop choices, we draw on original survey data collected

\section{Funding Disclosure}

The authors wish to acknowledge funding support from the International Treaty for Plant Genetic Resources for Food and Agriculture (ITPGRFA) Benefit Sharing Fund, the European Union, Bioversity International, and the University of Vermont Food Systems program. This work was implemented as part of the CGIAR Research Program on Climate Change, Agriculture and Food Security (CCAFS), which is carried out with support from the CGIAR Trust Fund and through bilateral funding agreements. For details, please visit https://ccafs.cgiar.org/donors. The views expressed in this document cannot be taken to reflect the official opinions of these organizations. 
from 1,001 rural households in Kenya, Tanzania, and Uganda. Bivariate and multivariate analyses suggest that female-headed households are less likely to grow cash crops, reflecting a combination of resource constraints and social norms. However, on average, female-headed households plant more diverse food crops per hectare of land to which they have access, consistent with past findings suggesting crop diversity is a strategy employed by resource-constrained female-headed households to meet household food security needs. We also find that women surveyed on behalf of their households place a higher value on crops for food security, while men more frequently emphasize income potential. These results provide novel cross-country evidence on how female- and maleheaded households, and women and men farmers within households, may prefer different crops and also face different levels of access to resources needed for market-oriented agriculture. Such findings support recent calls for development practitioners to carefully consider how marketoriented programs and policies may differentially affect female- and male-headed households and individuals residing within them. We also underscore the importance of collecting gender-disaggregated data to capture meaningful differences in preferences and constraints across women and men at the inter- and intra-household level.

\section{Keywords}

Agrobiodiversity, Smallholder Farmers, Gender, Crop Selection, Commercialization, East Africa

\section{Introduction}

Smallholder farmers worldwide, and especially in sub-Saharan Africa, are particularly vulnerable to poverty and food insecurity (Food and Agriculture Organization of the United Nations [FAO], UNICEF, WFP [World Food Program], \& World Health Organization [WHO], 2019; IFAD, 2016; Niles \& Salerno, 2018). Consequently, many development organizations have called for "pro-poor" agricultural development strategies, often centered on improving market access for smallholder farmers (Hellin, Lundy, \& Meijer, 2009, p. 16; Horton, 2008). Such approaches suggest that marketoriented development strategies can effectively address persistent rural poverty and food insecurity among diverse populations of smallholders operating in different social and agroecological contexts (Gengenbach, Schurman, Bassett, Munro, \& Moseley, 2018; Pingali, 2015; Toenniessen, Adesina, \& DeVries, 2008). To understand the applicability of these market-oriented approaches across different groups of smallholders, this paper investigates whether female-headed and maleheaded smallholder farmer households in three countries in East Africa differ in terms of the crops they choose to grow, and the opportunities and constraints they face.

Some of the most marginalized and food insecure populations in sub-Saharan Africa are women smallholders (Koppmair, Kassie, \& Qaim, 2017; Perez et al., 2015). Scholars and development organizations alike identify discrepancies in access to resources (e.g., land, agricultural inputs, credit) as key factors underlying production constraints and high rates of food insecurity among femaleheaded households (FAO, 2019; Peterman, Quisumbing, Berhman, \& Nkonya, 2011; Quisumbing et al., 2014). Some advocate market interventions targeting female-headed households as a development priority (Rubin \& Manfre, 2014). Gengenbach et al. (2018) note that market-oriented agricultural development approaches in Africa often focus on empowering female smallholders, as a means of increasing regional farm output and addressing household food and nutrition insecurity. However, they and several authors highlight limits of market-oriented interventions in promoting and achieving gender equity goals (Gengenbach et al., 2018; Meemken \& Qaim, 2018; Tavenner et al., 2019).

Some observers raise a concern that too often policymakers and development experts assume that most households will respond similarly to policies and development interventions, overlooking important differences across and within households (Quisumbing et al. 2014). The preferences and constraints of female-headed smallholder farm households can be very different from those of male-headed households; relatedly, the preferences and constraints of individual women (within either female- or male-headed households) can also be very different from those of men (Doss, Kovarik, 
Peterman, Quisumbing, \& van den Bold, 2015; Doss, Meinzen-Dick, Quisumbing, \& Theis, 2018). Such findings highlight a need to better understand how farm household livelihood choices, particularly those of female- and male-headed smallholder households, demonstrate different preferences and constraints across development contexts. A more nuanced understanding of differences in crop portfolios across household types, as well as differences in women's and men's individual crop choices within households, can inform development approaches in sub-Saharan African countries seeking to help households and individuals meet their goals and improve their wellbeing (Gengenbach et al., 2018).

In this paper, we use survey data from 1,001 smallholder farm households in East Africa to examine the degree to which female- and maleheaded households differ in the number and variety of crops they grow, the land and market constraints they face, and their values around crops for food security versus market sale. Specifically, the objectives of this paper include:

a) Describe the demographic profiles of female- and male-headed smallholder households in study communities in three countries-Kenya, Tanzania, and Uganda-where smallholder agriculture remains an important rural livelihood strategy, and rates of food and nutrition insecurity remain high (FAO et al., 2019; IFAD, 2016).

b) Characterize the crop portfolios of femaleand male-headed households in the sample, including the relative prevalence of food crops versus cash crops;

c) Identify relationships between household characteristics, particularly the gender of the household head, and household crop portfolios; d) Establish whether relationships between gender and crop choices persist when accounting for differences in resource constraints among female- and male-headed households, with a specific focus on land access; and

e) Determine whether female- and maleheaded households differ in the importance that they place on the crops they grow primarily for home consumption versus the crops they grow for income.

Collectively, these objectives allow us to provide insights into if and how female- and maleheaded households differ in their crop preferences and use, providing further understanding of how the gender of the household head relates to households' livelihood strategies. This analysis aims to contribute to broader scholarly debates around how different types of households are positioned to take advantage of market-oriented development approaches in sub-Saharan Africa. If the goal of enhancing market opportunities for smallholder women is to stimulate their competitiveness and empower them to transition out of poverty, then understanding what crops female-headed households grow and how they differ from male-headed households can help better align the assumptions of development theorists and practitioners with the realities of households' specific livelihood strategies. ${ }^{1}$

\section{Literature Review}

Since the 1960s, scholars have underscored the importance of including women in development efforts and advancing gender equity (Singh, 2007). These ideas gained traction in the 2000s among major development organizations, including the World Bank, FAO, USAID, and the CGIAR Consortium. All these organizations emphasize the need to overcome barriers women face in the

\footnotetext{
${ }^{1}$ Most of the data used in this study are at the household level. However, as we discuss in the literature review, we recognize there are important differences between household and individual characteristics, such that, for example, the preferences and constraints of male-headed households do not necessarily reflect those of the women who reside within those households (Quisumbing et al., 2014). Where possible, our analysis examines these differences empirically, including by asking how women and men respondents (including a large number of women responding on behalf of a male-headed household in our survey) differ in the importance that they place on the crops they grow.
} 
agricultural sector in order to realize poverty alleviation and food security goals. Often these organizations' gender strategies have a substantial market focus. For example, the World Bank has outlined ten policy priorities to close the gender gap in African agriculture, with more than half focused on improving women's access to agricultural inputs (e.g., improved seed) or output markets (e.g., sales of high-value cash crops) (O'Sullivan, Rao, Banerjee, Gulati, \& Vinez, 2014). Rubin and Manfre (2014) further highlighted the need to develop gender-equitable value chains (defined as all the activities and processes to bring a food product from conception to consumption and disposal) (Kaplinsky, 2000).

Developing competitive value chain opportunities for smallholders has become a hallmark strategy of major development organizations in sub-Saharan Africa (Gengenbach et al., 2018), with efforts focusing on a diverse array of crops from cassava leaves (Andersson, Lodin, \& Chiwona-Karltun, 2016) and tea (Loconto, 2015) in Tanzania to pigeonpeas in Malawi (Me-Nsope \& Larkins, 2016) and potatoes and sweet potatoes in Uganda (Horton et al., 2010). But empirical evidence consistently points to difficulties in changing existing dynamics among men and women in terms of control of resources and power relations across these varied value chains (Loconto, 2015; Malapit \& Quisumbing, 2015; Meemken \& Qaim, 2018; Rubin \& Manfre, 2014). Research examining intra-household gender dynamics suggests that men and women can differ in their crop preferences and adoption of crop varieties. For example, although both men and women consider production traits such as yield when selecting crops, men more often emphasize commercial potential while women more often highlight food processing and preparation traits (Bentley et al., 2017; Christinck, Weltzien, Rattunde, \& Ashby, 2017; Mudege \& Walsh, 2016). In Kenya, Pincus, Croft, Roothaert, and Dubois (2018) note that women seed producers of indigenous vegetable varieties emphasize the importance of seed saving for household food security significantly more than men. At the household level, the gender of the household head also appears to influence crops grown and the resulting livelihood outcomes. For example, Jones, Shrinivas, and Bezner-Kerr (2014) find that female-headed households in Malawi have a stronger association between higher crop diversity and household dietary diversity than male-headed households. Across Africa, women have been found to be key conservers of crop diversity (Amri \& Kimaro, 2010; Wooten, 2003), although in some instances better access to land and other productive resources appear to facilitate a more diverse portfolio of crops for men than women (Nuijten, 2010).

Gengenbach et al. (2018) and others (Carr \& Thompson, 2014; Jost et al., 2016; Quisumbing et al., 2014) recognize that gender intersects with an array of individual, institutional, and contextual factors in shaping crop choices across households. Teeken et al. (2018) demonstrate the complexity of these interactions when they find no differences across preferences of men and women cassava farmers for some traits (high yield, root size, early maturity, and dry matter content) regardless of the geographic region in Nigeria, but strong regional differences in the importance rankings of these traits, such that farmers in regions more oriented towards markets place higher importance on yield and early maturing, while farmers in regions with more focus on home consumption highlight cooking time to a greater degree. For other traits, the authors find significant differences between women and men producers (e.g., women prioritize cooking and processing traits while men emphasize agronomic traits) regardless of region. Similarly, Waldman, Ortega, Richardson, Clay, \& Snapp (2016) conclude that gender is one among several variables, including income and geography, that determines the adoption of and preferences for legumes in Malawi. Differences in crop selection may also reflect institutional constraints limiting women's access to improved varieties, inputs, and information. In Uganda, Fisher and Carr (2015) find that men more commonly adopted droughttolerant maize, due to differences in land, credit, and information access that better position men to invest in these crops. Zimmerer, Carney, and Vanek (2015) note that men's emphasis on market sales in some regions of Africa could reduce 
women's access to land, cultivation of traditional crops, and maintenance of agrobiodiversity. In a large survey in Ethiopia, Kenya, and Tanzania, Tavenner et al. (2019) find that while greater onfarm crop and livestock diversity are associated with greater female control over resources, higher rates of commercialization are associated with more male control across all farming systems studied.

A recent review by Ampaire et al. (2019) concludes that although development efforts and agricultural policies in East Africa have increased awareness of gender differences, actual implementation has not addressed structural inequalities.

Rather, the diverse and context-specific relationships between gender and agricultural production systems are often overlooked (Carr \& Thompson, 2014). Furthermore, while a growing body of literature focuses on gendered differences related to crop selection-with findings consistently suggesting women's crop production is constrained by resource limitations-most studies are limited in geographical scope. By analyzing data across three East African countries using an identical survey instrument, this study provides comparable find-

\section{Figure 1. Study Communities in Kenya, Tanzania, and Uganda}

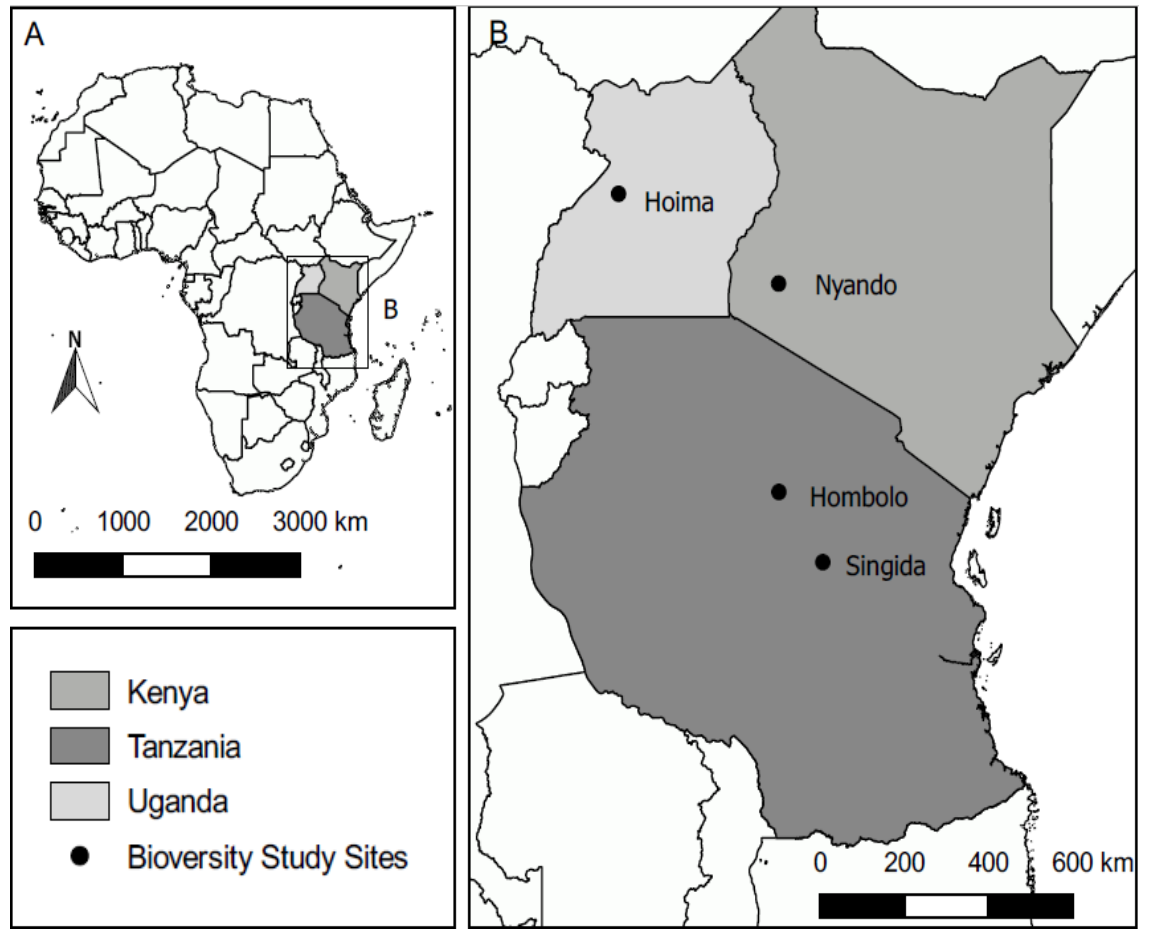

ings across diverse study contexts. It thus adds to the base of empirical evidence needed to enhance context-specific understanding of gendered implications of market-centered agricultural development efforts.

\section{Materials and Methods}

\section{Site Description}

Eastern Africa has some of the highest rates of undernutrition and childhood stunting globally (FAO et al., 2019). Within the region, Kenya, Tanzania, and Uganda are ranked $87^{\text {th }}, 98^{\text {th }}$, and $89^{\text {th }}$ of 113 countries in overall national food security, respectively (The Economist Intelligence Unit, 2018). Case study countries and study sites were selected by the international agricultural research institute, Bioversity International, to be representative of the primary agroecological systems in the region, and include four sites: Nyando in Kenya; Hombolo and Singida in Tanzania; and Hoima in Uganda (Figure 1).

As in many other parts of sub-Saharan Africa, smallholder agriculture is the primary livelihood strategy for rural populations in the study areas. And although there is high agricultural potential across all three countries, large yield gaps remain between that potential and what is actually produced. Policymakers and development practitioners have thus placed a strong emphasis on market-oriented development efforts. Between 2007 and 2016, all three countries were among the highest national recipients in terms of the number of grants provided by the Alliance for a Green Revolution in Africa [AGRA] (2017), and both Kenya and Uganda are Feed the Future countries with which the U.S. government partners to target food insecurity. Important regional staple crops have also been 
identified as holding potential for value chain development including maize, sweet potato, rice, sorghum, millet, beans, pigeonpeas, cassava, and groundnuts. Agricultural characteristics of the study sites are summarized in Table 1.

\section{Sampling Design}

The research team adopted a snowball sampling approach common in network surveys (Sudman \& Kalton, 1986), with researchers initially interviewing two nodal farmers, ${ }^{2}$ a male and female, identified during focus group discussions in each village as having influence or leadership roles in their community. As part of the survey, farmers were asked whom they had either received seeds from or given seeds to- - establishing the next cohort of farmers to interview. Participants were also asked to name the varieties of sorghum, millet, and bean seeds they had used in the last year and where they sourced the seed (e.g., local markets, research and extension services, private companies, or other farmers). Enumerators then surveyed farmers named by the first two respondents, and this sampling continued iteratively until interviewed farmers began mentioning the same names, or until no remaining farmers stated sourcing seed from others in the village.

The survey team then randomly selected a new set of interviewees in the next village and repeated the process until the target sample size was attained.

\section{Data Collection}

Survey data were collected from July through October 2016 using the Open Data Kit (ODK) survey platform, which allows data to be immediately entered and coded using tablets on site.

The survey collected household-level data, including the gender of the household head, farmer age, educational attainment, sources of on- and offfarm income, and households' gender and age composition. Farm-level data included farm assets, total land area and area of cropland managed by the household, and the geographic location of the farm, including distance to the nearest paved road and distance to market. The network survey module also included sources of expert information and farmers' contact with experts and extension services.

At the crop level, survey data included the number and type of crops grown for 22 specific crops plus one "other crop" category. As shown in Table 2, we also consider the number of different food groups grown by each household, classified according to the household dietary diversity score (HDDS) defined by Kennedy et al. (2011) on behalf of the Food and Agriculture Organization of the United Nations (FAO). This food group diversity score ranges from 1 (household grew only one crop or a combination of crops all from one HDDS category) to 5 (household grew at least one each of Cereals, White roots/tubers, Legumes, Dark leafy vegetables, and Other vegetables or

Table 1. Summary Information for the Study Sites in Kenya, Tanzania, and Uganda

\begin{tabular}{|c|c|c|c|c|c|}
\hline & \multicolumn{2}{|c|}{ Kenya } & \multicolumn{2}{|c|}{ Tanzania } & \multirow{2}{*}{$\begin{array}{c}\text { Uganda } \\
\text { Hoima }\end{array}$} \\
\hline & Nyando (Lower) & Nyando (Upper) & Hombolo & Singida & \\
\hline Farming system & $\begin{array}{c}\text { Mixed } \\
\text { subsistence }\end{array}$ & $\begin{array}{c}\text { Mixed } \\
\text { subsistence to } \\
\text { commercial }\end{array}$ & $\begin{array}{c}\text { Mixed } \\
\text { subsistence }\end{array}$ & $\begin{array}{c}\text { Mixed } \\
\text { subsistence }\end{array}$ & $\begin{array}{c}\text { Mixed } \\
\text { subsistence }\end{array}$ \\
\hline Agroecology & $\begin{array}{l}\text { Semi-arid / } \\
\text { sub-humid }\end{array}$ & Sub-humid & Semi-arid & $\begin{array}{l}\text { Semi-arid / } \\
\text { Sub-humid }\end{array}$ & Sub-humid \\
\hline Average rainfall (mm) & 800 & 1220 & 400 & 600 & 1200 \\
\hline Temperatures (degrees C.) & $18-34$ & $12-30$ & $12-35$ & $12-30$ & $12-32$ \\
\hline Altitude (m. above sea level) & $1100-1300$ & $1200-1400$ & 1100 & 1500 & 1120 \\
\hline Market accessibility & Very good & Very good & Poor & Moderate & Very good \\
\hline
\end{tabular}

${ }^{2}$ Nodal farmers are prominent farmers within a given community, expected to have a large number of connections with other farmers (i.e., to be "nodes" within a relatively large network). 
fruits). ${ }^{3}$ Finally, we further classify crops according to whether they are grown for primarily home consumption (i.e., staples) or if they are more typically grown for a combination of home consumption and market sale-including some commonly sold cereal crops, as well as higher-value vegetable, fruit, and other cash-crops (Table 2).

\section{Data Analysis}

All statistical analyses were conducted in Stata 15.1.

We first present basic descriptive statistics to summarize the demographic profiles of the households of survey respondents (objective a) and the crop portfolios of households according to the gender of the household head (objective b). We use independent samples t-tests, ANOVA, bivariate linear regression, or Pearson Chi-square tests for initial bivariate analyses considering the number and type of crops grown by farmers as a function of farm and household characteristics. Then, to further examine relationships between household characteristics and crop selection with a focus on the gender of the household head (objective c), we use multivariate models including ordinary least squares (OLS) regression in the case of continuous outcome variables, or ordinal logistic regression in the case of ordered categorical response variables.

Our first outcome of interest is crop diversity - measured by the number of crops planted by the household $\left(N_{\text {crops }}\right)$. This is a simple sum of the number of different crops planted, a continuous variable ranging from 1 to 23 . We hypothesize that female-headed households might plant fewer crops than male-headed households, due to a combination of resource constraints and gender norms that lead male-headed households to

Table 2. Crop Classification by Household Dietary Diversity Score (HDDS) Categories and Common Local Usage

\begin{tabular}{|c|c|c|c|}
\hline HDDS Category & Crops & $\begin{array}{c}\text { Primarily home } \\
\text { consumption }\end{array}$ & $\begin{array}{l}\text { Mixed consumption } \\
\text { and market sale }\end{array}$ \\
\hline Cereals & $\begin{array}{l}\text { Maize } \\
\text { Millet } \\
\text { Rice } \\
\text { Sorghum }\end{array}$ & & $\begin{array}{l}\sqrt{ } \\
\sqrt{ } \\
\sqrt{ } \\
\sqrt{ }\end{array}$ \\
\hline White roots and tubers & $\begin{array}{l}\text { Banana } \\
\text { Cassava } \\
\text { Sweet potato }\end{array}$ & $\begin{array}{l}\sqrt{ } \\
\sqrt{ } \\
\sqrt{ }\end{array}$ & $\begin{array}{l}{[\sqrt{ } \text { in Uganda }]} \\
{[\sqrt{ } \text { in Uganda }]} \\
{[\sqrt{ } \text { in Uganda }]}\end{array}$ \\
\hline Legumes & $\begin{array}{l}\text { Beans } \\
\text { Cowpea } \\
\text { Groundnut } \\
\text { Pigeonpea }\end{array}$ & $\begin{array}{l}\sqrt{ } \\
\sqrt{ } \\
\sqrt{ }\end{array}$ & $\sqrt{ }$ \\
\hline Dark green leafy vegetables & $\begin{array}{l}\text { Dodo (Amaranth) } \\
\text { Sukuuma wiki (Collard greens) } \\
\text { Nakati (Solanum aethiopioum) }\end{array}$ & $\sqrt{ }$ & $\begin{array}{l}\sqrt{ } \\
\sqrt{ }\end{array}$ \\
\hline Other vegetables & $\begin{array}{l}\text { Butternut } \\
\text { Cabbage } \\
\text { Onion } \\
\text { Pumpkin } \\
\text { Tomato }\end{array}$ & $\sqrt{ }$ & $\begin{array}{l}\sqrt{ } \\
\sqrt{ } \\
\sqrt{ } \\
\sqrt{ }\end{array}$ \\
\hline Other fruits & Watermelon & $\sqrt{ }$ & \\
\hline Other crops & $\begin{array}{l}\text { Coffee } \\
\text { Forages } \\
\text { Other crops }\end{array}$ & & $\begin{array}{l}\sqrt{ } \\
\sqrt{ } \\
\sqrt{ }\end{array}$ \\
\hline
\end{tabular}

Source: Household dietary diversity score (HDDS) categories from Kennedy, Ballard, and Dop (2011); crop uses are derived from author knowledge of the study area.

${ }^{3}$ We consider the category "Other crops" separately as these are less common in the sample and tend to be grown as cash crops (e.g., coffee) or are non-food (e.g., forages). 
plant more relatively new crops-e.g., other vegetables, other fruits, and other crops (e.g., coffee) for market sale - at higher rates than female-headed households. The Model 1 regression takes the form:

$N_{\text {crops }_{i}}=\beta_{0}+\beta_{1} x_{\text {Gender } H_{i}}+\beta_{2} x_{\text {AgeH }_{i}}+$ $\beta_{3} x_{\text {EducH }_{i}}+\beta_{4} x_{\text {OffFarmInc }_{i}}+\beta_{5} x_{\text {AdultsHH }_{i}}+$ $\beta_{6} x_{\text {Dependency }_{i}}+\beta_{7} x_{\text {Landholding }_{i}}+$ $\beta_{8} x_{\text {Distance_market }_{i}}+\beta_{9} x_{\text {Mobile }_{i}}+\beta_{10} x_{\text {Network }_{i}}+\varepsilon_{i}$

(Model 1-2)

Demographic variables hypothesized to relate to crop choices in addition to the gender of the household head (GenderHH) include the age of the household head $(\mathrm{AgeHH})$, and the educational attainment of the household head (EducHH), an ordinal variable including four levels ranging from no education to completion of some secondary school or above. Access to off-farm income (OffFarmInc) is a binary variable coded as 1 if the household had access to any off-farm income sources. To control for on-farm family labor, we use two variables: the number of adults in the household (AdultsHH) and the dependency ratio (Dependency), defined as the percentage of dependents aged less than 15, or over 60 (Hadley, Belachew, Lindstrom, \& Tessema, 2011) in the household. As both a measure of wealth and access to productive agricultural resources, we also include Landholding (hectares). Distance to market (kilometers) is included as a proxy for market access. Access to information and broader social capital is accounted for via two variables: ownership of a mobile phone (Mobile) and extent of social networks (Network), as measured by the number of other farmers from whom respondents received seed in the previous year. In Model 2 we further consider the number of different HDDS-based food crops $\left(N_{b d d s}\right)$, ranging from 1 to 15 , using the same regression model specification as Model 1 but focusing only on food crops traditionally grown in the study area.

In Model 3 we then consider aggregated HDDS food crop categories ( $N_{\text {bdds_cat }}$ ) grown by the household, measured as a scale ranging from 1 to 5. We hypothesize that female-headed households might be more likely to plant a more nutritionally diverse portfolio of crops-composed of at least one each of cereals, white roots/tubers, legumes, dark green leafy vegetables, and other vegetables and fruits - while male-headed households either specialize in certain food crops or allocate more resources to modern crops (including cash crops) rather than more diverse staples.

$$
\begin{aligned}
& N_{\text {hdds_cat }_{i}}=\beta_{0}+\beta_{1} x_{\text {Gender H }_{i}}+\beta_{2} x_{\text {AgeHH}_{i}}+ \\
& \beta_{3} x_{\text {EducH }_{i}}+\beta_{4} x_{\text {OffFarmInc }_{i}}+\beta_{5} x_{\text {AdultsH H }_{i}}+ \\
& \beta_{6} x_{\text {Dependency }_{i}}+\beta_{7} x_{\text {Landholding }_{i}}+ \\
& \beta_{8} x_{\text {Distance_market }_{i}}+\beta_{9} x_{\text {Mobile }_{i}}+\beta_{10} x_{\text {Network }_{i}}+\varepsilon_{i}
\end{aligned}
$$

(Model 3)

Due to the limited number of possible values for the outcome variable $N_{\text {bdds_cat }}$, we applied ordinal logistic regression models for Model 3. However, for ease of interpretation, we present OLS regression estimates, which yielded qualitatively similar findings to ordinal logistic regression methods.

We then seek to understand the degree to which the relationships between gender of the household head and crop choices identified in the above analyses hold when accounting for land access (objective d). In Model 4, we consider a revised dependent variable constructed to account for land constraints disproportionately shaping women's crop choices: the number of HDDSbased food categories grown per acre available land

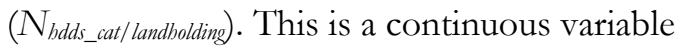
reflecting the diversity of food crops grown per unit of household land resources. We hypothesize that female-headed households might be relatively more likely than male-headed households to cultivate a more diverse portfolio of food crops after accounting for land resource constraints. Owing to the heavy right-skew of the variable, we use a $\log$ transformation in the OLS regression models:

$$
\begin{aligned}
& \ln \left(\frac{N_{\text {hdds_cat }}}{\text { Landholding }}\right)=\beta_{0}+\beta_{1} x_{\text {GenderH }_{i}}+\beta_{2} x_{\text {AgeH }_{i}}+ \\
& \beta_{3} x_{\text {EducH }_{i}}++\beta_{4} x_{\text {OffFarmInc }_{i}}+\beta_{5} x_{\text {AdultsHH }_{i}}+ \\
& \beta_{6} x_{\text {Dependenc }_{i}}+\beta_{7} x_{\text {Landholding }_{i}}+\beta_{8} x_{\text {Distance_market }_{i}}+ \\
& \beta_{9} x_{\text {Mobile }_{i}}+\beta_{10} x_{\text {Network }_{i}}+\varepsilon_{i}
\end{aligned}
$$

(Model 4) 
The land variable Landholding is omitted from the right-hand side of the equation to avoid multicollinearity for HDDS-based food categories grown per acre available land.

A final set of multivariate analyses (Models 58) focuses on objective e: whether female-headed households' crop choices reflect gendered preferences around crops primarily grown for household consumption and nutrition versus crops primarily grown for market sale. Namely, we compare rates of planting crops grown primarily for home consumption (Table 3) versus those grown for a combination of home consumption and market sale, including high-value vegetable, fruit, and other cash-crops (coffee, forages). These models are applied across female-headed and male-headed households in the sample using regression models identical to those previously used for food crops, but with the outcome variables total consumption crops grown ( $N_{\text {consumption }}$, and total mixed consumption and income crops grown $\left(N_{\text {mixed }}\right)$. We also model the logged outcome variables $\ln \left(N_{\text {consumption/landbolding }}\right)$ and $\ln \left(N_{\text {mixed/landbolding }}\right)$ - to consider the number of consumption crops grown per hectare of landholding, as well as the number of mixed consumption and income crops per hectare-to account for possible land constraints shaping crop choices.

Lastly, to further explore the degree to which differences in crop choices across female- and male-headed households might reflect different preferences regarding food crops versus income crops (objective e), we examine responses to two sets of survey questions. We asked respondents to report, for each crop planted among the 23 crops on the survey, the importance of that crop for (i) household food security, and (ii) household incomes. Enumerators collected responses on a 3point Likert scale, with the categories "Not Important," "Somewhat Important," and "Very Important." We hypothesize that due to social norms and resource constraints, female-headed households might be relatively more likely to assign high value to food security criteria when making choices about which crops to plant, while male-headed households might place more emphasis on incomegenerating potential.

\section{Alternative Gender Measures and Limitations}

We acknowledge that a wealth of recent scholarship critiques the over-reliance of development research on the household as the unit of analysis, arguing that a unitary household model (i.e., assuming that the responses of the household head represent the interests of the household members) misses important power differentials within rural households (Anderson, Reynolds, \& Gugerty, 2017; Quisumbing et al., 2014). As a result, measurements to account for women's empowerment and gender parity within female- and male-headed agricultural households have recently appeared and are being increasingly implemented (Larson, Castellanos, \& Jensen, 2019; Malapit, Kovarik, Sproule, Meinzen-Dick, \& Quisumbing, 2015). Our analysis relies on the household as the unit of analysis, with the respondent identifying the person in the household who serves as the head. Though we acknowledge this does not reveal dynamics within the household, it does provide insight into how the gender make-up of households may influence crop choices-and thus contributes to better understanding the complexities of gender and its effects on decision-making and resource allocation in rural agrarian contexts.

In addition, recognizing that preferences and priorities identified at the household level may obscure the perspectives of individuals residing within those households (Doss et al., 2018; Gengenbach et al., 2018; Quisumbing et al., 2014), in the final bivariate tests comparing rankings of relative importance assigned to the nutritional versus income values of the food and cash crops grown by gender of the household head, we further compare importance rankings by gender of the survey respondent. Although $67 \%$ of households in the sample had a male head-of-household, women provided responses for $41 \%$ of the maleheaded households surveyed (responding on behalf of a male household head). In exploring how the responses of women in male-headed households might differ from male household heads' own selfreported importance ratings, we can begin to see how values around nutritional versus income benefits from crops might differ across genders (rather than across gender of the household head alone). 


\section{Results}

Objective a: Demographic profile of the sample

Table 3 provides summary statistics disaggregated by country and gender of the household head. Roughly one-third of sampled households in each country are female-headed, ranging from $28 \%$ in Kenya to $36 \%$ in Tanzania. Female household heads are on average older than male household heads in Kenya $(\mathrm{t}=2.71, \mathrm{p}=0.004)$, but this is not the case in Tanzania or Uganda. Consistent with national trends, female respondents in all countries have lower education rates; in Tanzania and Uganda, female-headed households are also less likely to have off-farm income $\left(\chi^{2}=6.60\right.$, $p<0.010)$. Female-headed households also generally have fewer adults present (except in Uganda) and have significantly fewer land resources in all three countries $(t=5.09, p<0.001)$. Female-headed households are on average further away from markets, although this difference is only significant in Uganda $(\mathrm{t}=1.55, p<0.061)$. In Kenya and Tanzania, female-headed households are also less likely to own a mobile phone $\left(\chi^{2}=4.10, p<0.043\right)$. The extent of social networks - measured by the number of farmers from whom a household received seeds-varies across countries. Femaleheaded households reported more network ties than male-headed ones in Uganda $(\mathrm{t}=1.53$, $p=0.064$ ), but there were no reported network differences across household types in Kenya or Tanzania.

Objective b: Household crop production by country and gender of the household head

We next turn to descriptions of the crop produc-

Table 3. Sample Descriptive Statistics by Country and Gender of the Household Head

\begin{tabular}{|c|c|c|c|c|c|c|}
\hline \multirow[b]{2}{*}{ Gender of household head: } & \multicolumn{2}{|c|}{ Kenya $(n=364)$} & \multicolumn{2}{|c|}{ Tanzania $(n=334)$} & \multicolumn{2}{|c|}{ Uganda $(n=303)$} \\
\hline & $\begin{array}{c}\text { Female } \\
(28 \%)\end{array}$ & $\begin{array}{l}\text { Male } \\
(72 \%)\end{array}$ & $\begin{array}{c}\text { Female } \\
(36 \%)\end{array}$ & $\begin{array}{l}\text { Male } \\
(64 \%)\end{array}$ & $\begin{array}{c}\text { Female } \\
(35 \%)\end{array}$ & $\begin{array}{l}\text { Male } \\
(65 \%)\end{array}$ \\
\hline \multicolumn{7}{|l|}{ Age of head (\%) } \\
\hline $15-20$ & 0 & 0 & 1.7 & 0.5 & 1.9 & 1.5 \\
\hline $21-30$ & 5.9 & 7.7 & 10.1 & 5.6 & 14.4 & 13.2 \\
\hline $31-44$ & 22.6 & 38.7 & 32.8 & 33.5 & 36.5 & 41.1 \\
\hline$\geq 45$ & 71.6 & 53.6 & 55.5 & 60.5 & 47.1 & 44.2 \\
\hline \multicolumn{7}{|l|}{ Education of head (\%) } \\
\hline None & 25.5 & 7.3 & 39.5 & 21.9 & 17.9 & 11.2 \\
\hline Basic & 22.6 & 26.3 & 19.3 & 14.9 & 26.4 & 25.9 \\
\hline Primary & 34.3 & 24.8 & 37.0 & 54.4 & 33.0 & 35.0 \\
\hline Some secondary & 16.7 & 36.6 & 2.5 & 6.1 & 21.7 & 25.9 \\
\hline Secondary or greater & 1.0 & 5.0 & 1.7 & 2.8 & 1.0 & 2.0 \\
\hline Off-farm income (yes=1) & 0.41 & 0.39 & 0.60 & 0.74 & 0.36 & 0.51 \\
\hline \multicolumn{7}{|l|}{ Labor availability (mean) } \\
\hline Household members & 5.90 & 6.42 & 5.28 & 6.51 & 6.55 & 6.10 \\
\hline Adult female & 1.84 & 1.78 & 1.82 & 1.64 & 2.10 & 1.52 \\
\hline Adult male & 1.67 & 1.98 & 1.37 & 1.95 & 1.48 & 1.69 \\
\hline Dependents & 2.32 & 2.95 & 2.36 & 3.03 & 2.98 & 3.25 \\
\hline Dependency ratio (\% dep) & 43.8 & 47.3 & 45.1 & 45.6 & 44.6 & 50.2 \\
\hline Landholding (mean acres) & 5.58 & 6.25 & 5.14 & 8.08 & 5.57 & 6.94 \\
\hline Cropland (mean acres) & 2.32 & 2.47 & 4.28 & 6.58 & 3.53 & 5.41 \\
\hline Distance to market (mean km) & 10.18 & 9.07 & 3.65 & 3.57 & 4.74 & 4.11 \\
\hline Mobile phone (yes=1) & 0.79 & 0.90 & 0.61 & 0.71 & 0.86 & 0.90 \\
\hline Network ties (mean) a & 0.66 & 0.73 & 0.79 & 0.82 & 0.59 & 0.46 \\
\hline
\end{tabular}

a Network ties represent the number of other farmers from whom the respondent received seed (including zero for farmers receiving no seed from others), in the network module of the survey. 
tion of the households in the sample across genders (gender of the household head) and countries. We summarize households' crop portfolios in several ways, beginning with a basic count of the number of species grown, followed by the percentage of households that grow each kind of crop. We then proceed to a breakdown of crop production according to HDDS food crop categories.

As shown in Figure 2 and consistent with past findings from the region (Tavenner et al., 2019), both female- and male-headed households in the sample overwhelmingly plant multiple crops. On average, male-headed households plant more crops overall: in bivariate t-tests having a female head is associated with 0.55 fewer crops planted in Kenya $(\mathrm{t}=1.79, p=0.037), 1.19$ fewer crops in Tanzania $(\mathrm{t}=3.91, p<0.001)$, and 0.61 fewer crops in Uganda $(\mathrm{t}=1.95, p=0.026){ }^{4}$

Table 4 shows the frequencies with which female- versus male-headed households grew specific food crops in each country. Differences in crop portfolios are apparent across countries, reflecting regional agroecologies, cultural food preferences, and/or local market demand. These differences are also reflected across genders within countries, possibly reflecting gender norms and

Figure 2. Number of Crops Grown by Sample Households

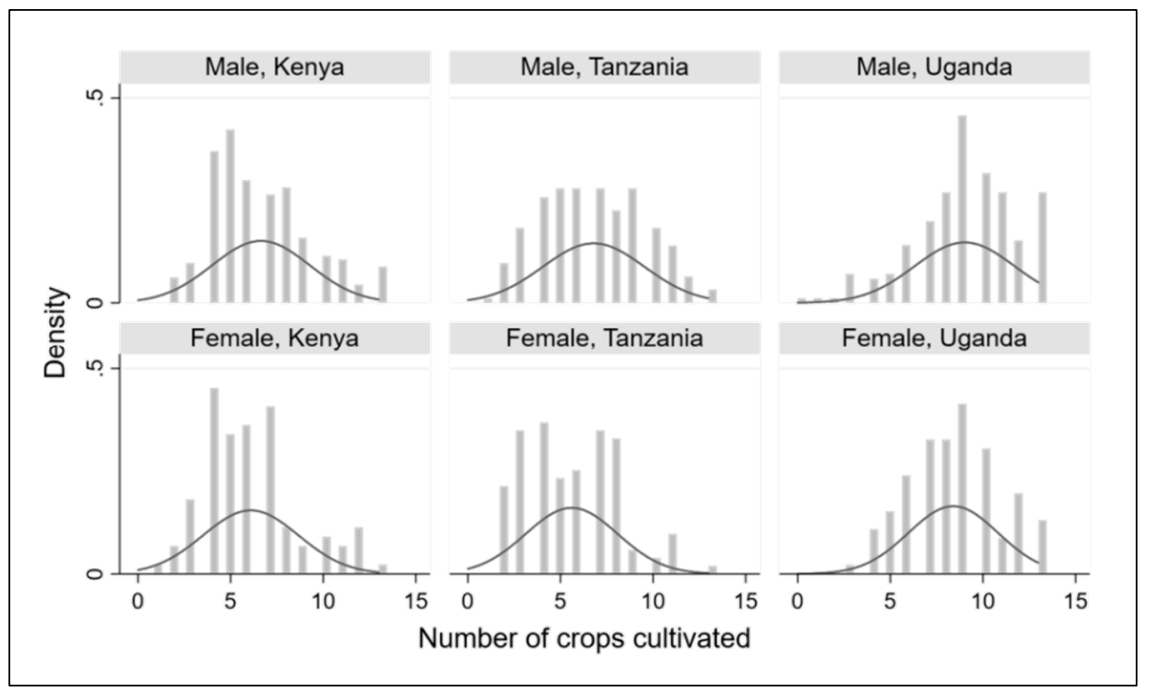

differences in resource access. Among grain crops, maize is the most commonly grown in all households and countries. Sorghum is common in Kenya, relatively uncommon in Uganda, and somewhat common in Tanzania, but more so among male-headed households. Millet is grown by roughly one-third of female- and male-headed households in Kenya but less so in Tanzania or Uganda. Though relatively uncommon for respondents in all countries, rice is most likely to be grown by male-headed households in Tanzania or Uganda. Among the remaining food crops, several others are also more likely to be found in male-headed households including cowpea, cabbage, pumpkin, and tomato in all countries, as well as groundnut, pigeonpea, and sweet potato in Tanzania, sukuma wiki (collard greens) in Kenya, and nakati (Solanum aethiopioum) in Uganda. Such patterns may reflect many of these crops being considered to be more "men's crops" than "women's crops" in these country contextsindeed the only crop substantially more common in female-headed households is groundnut in Uganda (grown by $84.9 \%$ of female-headed households versus $73.6 \%$ of male-headed). However, in any categorization of "women's crops" versus "men's crops," it should be noted that within any given household, both women and men may participate in crop production. For example, Nakazi et al. (2017) describe how both men and women in Uganda widely contribute to the production of beans, even though this has traditionally been identified as a "women's crop." Relatedly, "women's crops" may be cultivated by women within male-headed households and vice versa. Thus, the household-level summary findings we present

\footnotetext{
${ }^{4}$ In Kenya the median count of crops per household was 6 in both female- and male-headed households. In Tanzania and Uganda the median male-headed households planted more crops than female-headed, with a median of 7 (male) versus 6 (female) in Tanzania, and a median of 9 (male) versus 8 (female) in Uganda.
} 
Table 4. Food Crops Grown, Percent of Households by Country and Gender of the Household Head

\begin{tabular}{|c|c|c|c|c|c|c|c|}
\hline \multirow[b]{2}{*}{ Category } & \multirow[b]{2}{*}{ Crop } & \multicolumn{2}{|c|}{ Kenya $(n=364)$} & \multicolumn{2}{|c|}{ Tanzania $(n=334)$} & \multicolumn{2}{|c|}{ Uganda $(n=303)$} \\
\hline & & Female & Male & Female & Male & Female & Male \\
\hline \multirow[t]{4}{*}{ Cereals } & Maize & 97.1 & 96.9 & 94.1 & 92.6 & 92.5 & 89.8 \\
\hline & Sorghum & 90.1 & 92.7 & 67.2 & 76.7 & 13.2 & 15.7 \\
\hline & Millet & 31.3 & 37.4 & 16.8 & 17.7 & 17.9 & 16.2 \\
\hline & Rice & 1.0 & 0.4 & 6.7 & 12.6 & 9.4 & 19.8 \\
\hline \multirow[t]{4}{*}{ Legumes } & Bean & 81.4 & 86.2 & 47.9 & 43.3 & 100.0 & 97.8 \\
\hline & Groundnut & 33.3 & 30.9 & 68.9 & 78.6 & 84.9 & 73.6 \\
\hline & Cowpea & 56.9 & 64.8 & 47.9 & 54.0 & 25.5 & 33.0 \\
\hline & Pigeonpea & 7.8 & 8.0 & 11.8 & 29.3 & 32.1 & 36.5 \\
\hline \multirow[t]{3}{*}{ White starch } & Sweet potato & 27.4 & 26.7 & 10.1 & 19.5 & 94.3 & 93.9 \\
\hline & Cassava & 25.5 & 23.3 & 4.2 & 8.8 & 96.2 & 95.4 \\
\hline & Banana & 30.4 & 35.9 & 2.5 & 2.8 & 79.2 & 76.1 \\
\hline \multirow[t]{3}{*}{ Dark green } & Dodo & 13.7 & 16.0 & 12.6 & 15.8 & 69.8 & 68.0 \\
\hline & Sukuma wiki & 20.6 & 37.0 & 0 & 4.7 & 1.9 & 4.7 \\
\hline & Nakati & 16.7 & 17.5 & 16.8 & 24.7 & 47.2 & 62.9 \\
\hline \multirow[t]{5}{*}{ Other vegetables } & Butternut & 2.9 & 6.9 & 27.7 & 33.5 & 0 & 0 \\
\hline & Cabbage & 9.9 & 13.7 & 1.7 & 4.7 & 4.7 & 10.7 \\
\hline & Onion & 25.5 & 27.1 & 2.5 & 3.3 & 4.7 & 9.6 \\
\hline & Pumpkin & 21.6 & 26.7 & 48.7 & 60.9 & 17.0 & 25.8 \\
\hline & Tomato & 18.6 & 20.6 & 5.9 & 15.8 & 8.5 & 13.7 \\
\hline
\end{tabular}

may mask individual-level differences in cropping choices across genders within households (a distinction we revisit below).

When considering the aggregated HDDS food crop categories, for cereals, white starches, and legumes, we find little variation on average across female- and male-headed households in the sample-both appear equally likely to grow at least one cereal, white starch, or legume within a given country context (Table 5). In Uganda, more than $94 \%$ of both female- and male-headed households grow at least one cereal and at least one white starch and legume. In Kenya and Tanzania, white starches are less common overall. Dark green vegetables are most commonly grown in Uganda, followed by Kenya, and more common among male-headed households in all three countries.

Some of the most striking differences across

Table 5. Crop Categories Grown, Percent of Households by Country and Gender of the Household Head

\begin{tabular}{lcccccc}
\hline & \multicolumn{2}{c}{ Kenya $(n=364)$} & \multicolumn{2}{c}{ Tanzania $(n=334)$} & \multicolumn{2}{c}{ Uganda $(n=303)$} \\
Crop & Female & Male & Female & Male & Female & Male \\
\hline Cereals (any) & 99.0 & 100 & 99.2 & 99.1 & 93.4 & 93.9 \\
White roots and tubers (any) & 52.9 & 56.9 & 15.1 & 23.7 & 98.1 & 97.5 \\
Legumes (any) & 98.0 & 97.7 & 97.5 & 94.4 & 100 & 98.5 \\
Dark green leafy veg (any) & 36.3 & 49.2 & 20.2 & 32.6 & 71.7 & 77.2 \\
Other vegetables & 37.3 & 47.3 & 52.1 & 66.0 & 23.6 & 39.6 \\
Other fruits & 2.9 & 6.5 & 25.2 & 32.6 & 0 & 2.5 \\
Other crops & 4.9 & 5.0 & 41.2 & 50.7 & 2.8 & 9.6 \\
Coffee & 1.0 & 0.8 & 0 & 0 & 47.2 & 59.9 \\
Forages & 10.8 & 15.3 & 2.5 & 5.6 & 1.9 & 1.5 \\
\hline
\end{tabular}


household types in Table 5 are for crops commonly grown for market. Male-headed households are more likely to grow other vegetables (including various horticulture cash crops) across all study sites. In Uganda, male-headed households appear more likely to grow other fruits and other crops at much higher rates than female-headed households. Among sampled households in Uganda, where coffee cultivation is relatively more common, coffee is grown by nearly $60 \%$ of male-headed households-but only $47.2 \%$ of female-headed households. In Kenya, forages are more commonly grown than coffee, but are again more common among male-headed households. In aggregate, we see strong evidence of diverse cropping portfolios across countries and household types, with maleheaded households overall more likely to plant several key food and cash crops.
Objective c: Relationships between household characteristics and crop production

Our analysis proceeds to consider relationships between a household's characteristics and crop production, with a focus on the gender of the household head. In multivariate models for the total number of crops grown by households, we again see female-headed households on average grow significantly fewer crops than male-headed ones, even after controlling for a range of other individual and household characteristics (Table 6). Across all households in the sample, older household heads and those with more education grow more crops on average, as do those with access to off-farm income and larger landholdings. Access to a broader social network of other farmers is also associated with a larger number of crops planted (though the causal direction for this relationship is

Table 6. Correlates of the Total Number of Crops Grown (OLS Regression Models)

\begin{tabular}{|c|c|c|c|c|}
\hline & & \multicolumn{3}{|c|}{ Model 1: $N_{\text {crops }}$} \\
\hline & & All Households & Female-headed & Male-headed \\
\hline & Household head gender (female) & $-0.352 *$ & - & - \\
\hline \multirow{3}{*}{$\underset{\infty}{\stackrel{0}{\alpha}}$} & Young adult (15-30 years) & - & - & - \\
\hline & Middle-age adult (31-45 years) & 0.435 & 0.240 & 0.423 \\
\hline & Elder (>45 years) & $0.757 * *$ & $0.847 *$ & 0.578 \\
\hline \multirow{5}{*}{ 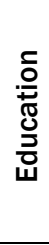 } & None & -- & - & - \\
\hline & Basic education & $0.502 *$ & $0.705 *$ & 0.467 \\
\hline & Completed primary school & $0.484 *$ & -0.031 & $0.726 * *$ \\
\hline & Some secondary school & $0.617 * *$ & 0.390 & $0.805 * *$ \\
\hline & Beyond secondary school & 0.847 & 1.118 & 0.987 \\
\hline \multirow{7}{*}{ 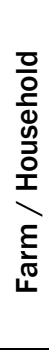 } & Off-farm income & $1.094 * * *$ & $1.518 * * *$ & $0.942 * * *$ \\
\hline & Adults in household & 0.012 & $0.118 *$ & -0.010 \\
\hline & Percent dependents & 0.344 & 0.158 & 0.511 \\
\hline & Landholding & $0.131 * * *$ & $0.094 * * *$ & $0.147 * * *$ \\
\hline & Distance to market & -0.019 & -0.047 & -0.014 \\
\hline & Mobile phone & 0.128 & 0.149 & 0.120 \\
\hline & Network ties & $0.319 * * *$ & 0.074 & $0.429 * * *$ \\
\hline \multirow{6}{*}{$\stackrel{ \pm}{*}$} & Kenya & - & - & - \\
\hline & Tanzania & $-0.488 * *$ & $-0.786 *$ & -0.367 \\
\hline & Uganda & $2.326 * * *$ & $2.288 * * *$ & $2.312 * * *$ \\
\hline & Constant & $4.259 * * *$ & $3.870 * * *$ & $3.713 * * *$ \\
\hline & Valid N & 927 & 305 & 622 \\
\hline & Adjusted R2 & 0.260 & 0.281 & 0.240 \\
\hline
\end{tabular}


ambiguous). Finally, we see significant differences across the three countries even after controlling for household characteristics, with more crops planted per household in Uganda, and fewer in Tanzania (relative to the reference country Kenya).

The gender-disaggregated regression models in Table 6 further suggest that female-headed and male-headed households in the sample face different constraints on the number of crops they grow. Age, for example, is significantly positively associated with the number of crops grown in female-headed households, but not in male-headed households. Education, meanwhile, is positively associated with the number of crops planted by male-headed households, but less so among female-headed (perhaps because constraints other than education weigh relatively more heavily on female-headed households). Both female- and male-headed households plant more crops when they have access to off-farm income, possibly reflecting market access for more diversified crop portfolios. Both female- and male-headed households also plant more crops when they have access to more landholdings - although for female-

headed households, access to labor (as measured by the number of adults in the household) is also a strong predictor of the number of crops grown, while male-headed households appear less responsive to family labor availability. This last finding may reflect male-headed households on average having more labor available than female-headed households (and hence potentially seeing diminishing marginal returns to additional labor). This difference in responsiveness to labor availability may also be due to male-headed households' relatively greater orientation towards diversified commercial crop production (regardless of available labor).

\section{Objective d: The moderating effect of land access on relationships between household characteristics and food crop production}

Given that resource constraints have been found to disproportionately affect production decisions among women smallholders (Quisumbing et al., 2014), we next seek to assess further how land availability might moderate relationships between gender of the household head and crop planting. As shown in Figure 3, landholding is significantly associated with the number of HDDS food crops planted among sample households (for the moment excluding cash crops such as coffee and forages). In simple bivariate tests, an additional hectare of landholding is associated with an additional 0.14 food crops in male-headed households $(\mathrm{F}(1,672)=46.36, p<0.001)$ and an additional 0.12 crops in female-headed households $(\mathrm{F}(1,325)=10.79, p<0.001)$ across the full sample.

In female-headed households having more than the median landholding is strongly associated with more food crop diversity, with women in the eighth or ninth decile of landholding most likely to grow four of the five HDDS food crop groups considered here. Households in the bottom decile of landholding grow the fewest different food groups across household types. Among both female- and male-headed households, however, we also see a decline in the cultivation of white roots and tubers at higher levels of landholding,

\section{Figure 3. Proportion of Households Growing Food Crop Groups, by Deciles of Landholding}

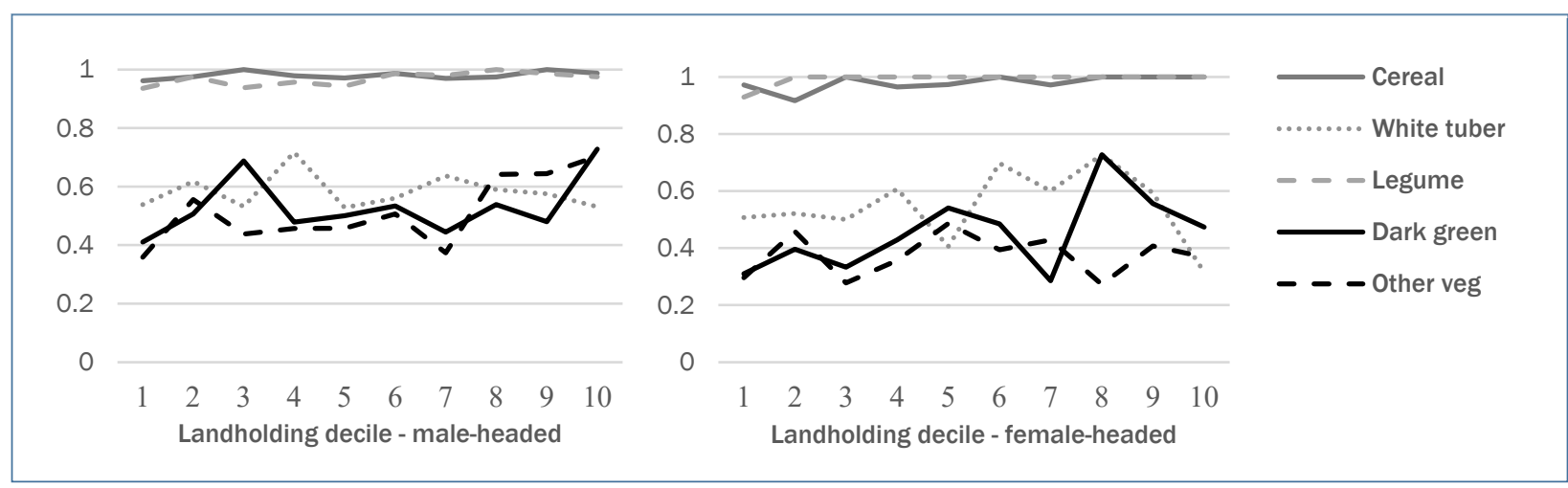


suggesting less food crop diversity with greater landholdings among at least some households.

Multivariate models for the total number of HDDS food groups grown by households in the sample are shown in Table 7 . While the previous regression in Table 6 suggests female-headed households on average plant fewer crops than male-headed households, in Model 2 in Table 7, we see no significant differences across female- and male-headed households in terms of the number of HDDS food crops planted. Rather, higher levels of education, access to off-farm income, greater landholding, and greater social network ties are the household attributes more consistently associated with the number of food crops grown. In Model 3, we do find a small negative association between gender of the household head and the number of aggregated HDDS food categories grown, with female-headed households on average planting
0.152 fewer HDDS food groups than male-headed households $(p=0.029)$. But in Model 4 we find a strong positive association between female household heads and the number of HDDS food crop categories planted per hectare of land available to them-suggesting that, after accounting for land resource constraints, female-headed households may be more likely to plant a diverse portfolio of food crops than male-headed households. On average female-headed households in the sample plant $17.5 \%$ more HDDS food crop categories per available hectare of land than male-headed households $(\operatorname{Exp}(\beta)=1.175, p<0.001)$. Significant crosscountry differences remain in all models.

Objective e: The importance of crops for market and home consumption among female-and malebeaded bouseholds

Our final set of regression analyses explores if and

Table 7. Correlates of the Number of HDDS Food Crops (hdds_crops) and the Number of Different Food Groups (hdds_cat) Grown, Both Overall and Per Hectare of Landholding

\begin{tabular}{|c|c|c|c|c|}
\hline & & $\begin{array}{l}\text { Model 2: } \\
\text { Nhdds_crops }\end{array}$ & $\begin{array}{c}\text { Model 3: } \\
\text { Nhdds_cat }\end{array}$ & $\begin{array}{c}\text { Model 4: } \\
\text { In(N } \text { Ndds_cat/ }_{\text {h }} \\
\text { Landholding) }\end{array}$ \\
\hline & & B & B & $\operatorname{Exp}(\beta)$ \\
\hline & Household head gender (female) & -0.284 & $-0.152 * *$ & $1.175 * * *$ \\
\hline \multirow{3}{*}{$\underset{\alpha}{\infty}$} & Young adult (15-30 years) & - & - & - \\
\hline & Middle age adult (31-45 years) & 0.427 & 0.057 & 0.895 \\
\hline & Elder (>45 years) & $0.648 * *$ & 0.160 & $0.828 * *$ \\
\hline \multirow{5}{*}{ 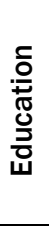 } & None & - & - & - \\
\hline & Basic education & $0.579 * *$ & $0.217 * *$ & $1.295 * * *$ \\
\hline & Completed primary school & $0.614 * *$ & 0.093 & $1.135 *$ \\
\hline & Some secondary school & $0.753 * * *$ & 0.121 & 1.108 \\
\hline & Beyond secondary school & $1.122 * *$ & 0.230 & 1.237 \\
\hline \multirow{7}{*}{ 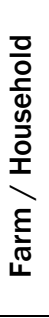 } & Off-farm income & $0.880 * * *$ & $0.318 * * *$ & 0.998 \\
\hline & Adults in the household & 0.018 & -0.004 & $0.968 * * *$ \\
\hline & Percent dependents & 0.198 & 0.071 & 0.913 \\
\hline & Landholding & $0.130 * * *$ & $0.033 * * *$ & - \\
\hline & Distance to market & -0.015 & -0.007 & $0.990 * *$ \\
\hline & Mobile phone & 0.176 & 0.028 & $0.840 * *$ \\
\hline & Network ties & $0.343 * * *$ & $0.075 * *$ & 1.027 \\
\hline \multirow{6}{*}{$\stackrel{\oplus}{\dot{*}}$} & Kenya & - & - & - \\
\hline & Tanzania & $-0.807 * * *$ & $-0.464 * * *$ & $0.818 * * *$ \\
\hline & Uganda & $1.895 * * *$ & $0.589 * * *$ & $1.124 *$ \\
\hline & Constant & $4.150 * * *$ & $3.019 * * *$ & 0.786 \\
\hline & Valid N & 927 & 927 & 922 \\
\hline & Adjusted R2 & 0.237 & 0.187 & 0.067 \\
\hline
\end{tabular}


Figure 4. Proportion of Households Growing Income Crop Groups, by Deciles of Landholding

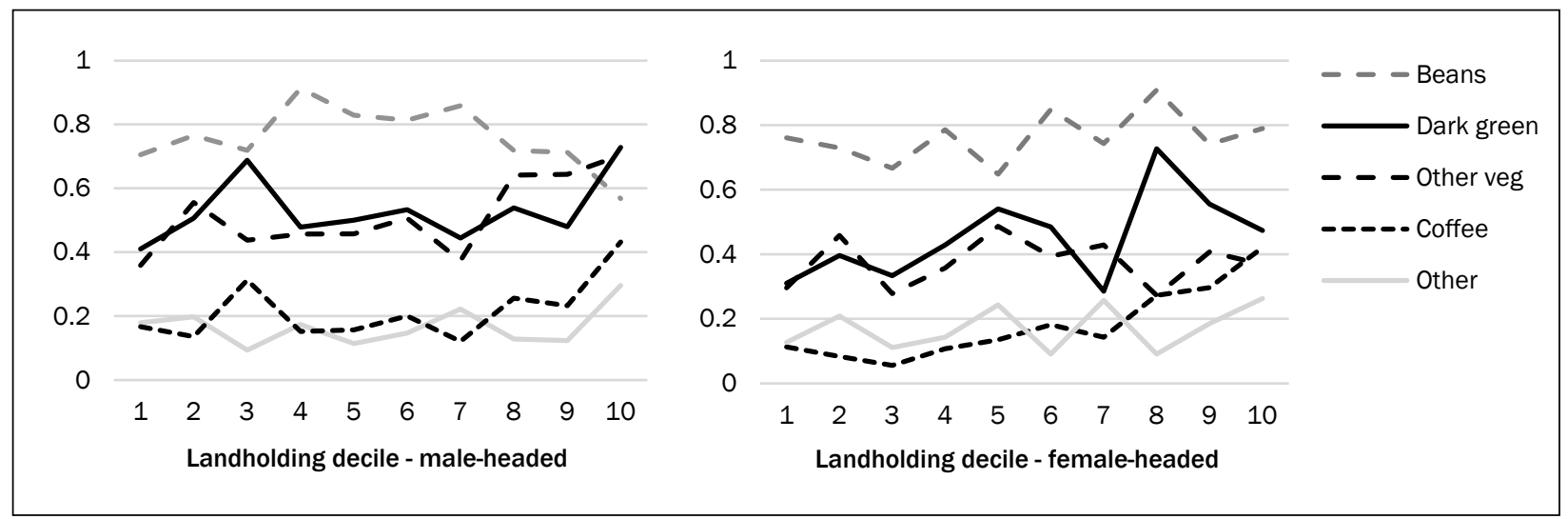

how female- and male-headed households value crops for home consumption versus for market sale differently. As with crops grown for food security, access to land remains a key constraint on the number of income crops planted by both household types (using consumption versus mixed consumption and income crop groupings shown in Table 3). Male-headed households appear more likely to allocate land to income crops. As shown in Figure 4, across almost all landholding deciles, male-headed households are more likely to grow income crops than female-headed households. Among both female- and male-headed households, those in the lowest (bottom decile) of landholding grow the fewest different income crops. However, female-headed households with limited landholding are much less likely to grow income crops than their male-headed counterparts. Bivariate tests suggest that, on average, an additional hectare of landholding is associated with an additional 0.08 income crops in male-headed households versus an additional 0.04 in female-headed households $(p<0.001)$.

In multivariate models for the total number of consumption crops versus mixed consumption and income crop groups grown, we again find a significant negative association between the household head being female and the number of crops grown, but only for more market-oriented crops (Table 8). In Model 5, female-headed households are no less likely than male-headed households to grow larger numbers of food crops primarily for consumption, but in Model 6, female-headed households appear less likely to plant additional income crops. After accounting for landholding, in Model 7, femaleheaded households are more likely to plant greater numbers of consumption crops on a given area of land, but not more likely than male-headed households to plant greater numbers of mixed consumption and income crops. Taken together, Models 5 through 8 suggest that given the same amount of land and other resources, female-headed households plant more crops for home-consumption, while male-headed households are relatively more likely to plant crops for mixed consumption and income. In all models, socioeconomic variables relating to education, off-farm income, land resources, market access, and social networks are the predictors most consistently associated with increased planting of mixed consumption-income crops. Again significant differences across countries remain after controlling for farm and household characteristics.

\section{Extension: Female and male individual perspectives on crop contributions to food security and household incomes}

Given the prominent differences in crop choices among female- and male-headed households observed through both bivariate and multivariate analyses, especially between crops typically consumed as food versus crops used for a mix of consumption and market sale, we further examined two survey questions that specifically asked respondents to report their perspectives on the food security importance of different crops, and 
Table 8. Correlates of Staple Food Versus Mixed Food-Income Crops Grown

\begin{tabular}{|c|c|c|c|c|c|}
\hline & & $\begin{array}{l}\text { Model 5: } \\
\text { Nconsumption }\end{array}$ & $\begin{array}{l}\text { Model 6: } \\
N_{\text {mixed }}\end{array}$ & $\begin{array}{c}\text { Model 7: } \\
\text { In( } \text { Nonsumption/ } \\
\text { Landholding })\end{array}$ & $\begin{array}{c}\text { Model 8: } \\
\ln \left(\mathrm{N}_{\text {mixed }} / \text { Landholding }\right) \\
\end{array}$ \\
\hline & & $\beta$ & $\beta$ & $\operatorname{Exp}(\beta)$ & $\operatorname{Exp}(\beta)$ \\
\hline & Household head gender (female) & -0.050 & $-0.312 * * *$ & $1.051 * *$ & 1.039 \\
\hline \multirow{3}{*}{$\stackrel{0}{\infty}$} & Young adult (15-30 years) & - & - & - & - \\
\hline & Middle age adult (31-45 years) & $0.487 * * *$ & -0.058 & $1.071 *$ & $0.926 *$ \\
\hline & Elder (>45 years) & $0.833 * * *$ & -0.095 & $1.101 * *$ & $0.896 * * *$ \\
\hline \multirow{5}{*}{ 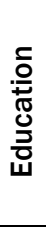 } & None & - & - & - & - \\
\hline & Basic education & 0.192 & $0.409 * *$ & $1.067 *$ & $1.120 * * *$ \\
\hline & Completed primary school & $0.472 * * *$ & 0.069 & $1.084 * *$ & 1.038 \\
\hline & Some secondary school & $0.665 * * *$ & 0.075 & $1.076 *$ & 1.011 \\
\hline & Beyond secondary school & $0.690 * *$ & $0.976 *$ & $1.178 * *$ & $1.141 *$ \\
\hline \multirow{7}{*}{ 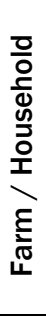 } & Off-farm income & $0.728 * * *$ & $0.351 * * *$ & $1.059 * *$ & 0.999 \\
\hline & Adults in the household & -0.002 & 0.027 & $0.989 * * *$ & $0.990 * *$ \\
\hline & Percent dependents & 0.237 & 0.055 & 0.997 & 0.968 \\
\hline & Landholding & $0.048 * * *$ & $0.115 * * *$ & - & - \\
\hline & Distance to market & 0.002 & $-0.016 *$ & 0.997 & $0.995 * *$ \\
\hline & Mobile phone & 0.002 & 0.068 & 0.953 & $0.942 *$ \\
\hline & Network ties & $0.143 * *$ & $0.251 * * *$ & $1.031 * *$ & $1.031 * *$ \\
\hline \multirow{6}{*}{$\stackrel{\oplus}{\dot{\omega}}$} & Kenya & - & - & - & - \\
\hline & Tanzania & 0.208 & $-1.101 * * *$ & 1.016 & $0.926 * *$ \\
\hline & Uganda & $2.742 * * *$ & 0.031 & $1.432 * * *$ & 1.026 \\
\hline & Constant & 0.364 & $4.264 * * *$ & $1.506 * * *$ & $2.167 * * *$ \\
\hline & Valid N & 927 & 927 & 923 & 923 \\
\hline & Adjusted R2 & 0.414 & 0.169 & 0.198 & 0.044 \\
\hline
\end{tabular}

the income security importance of these same crops, as summarized in Figure 5. Owing to the way these questions were asked-i.e., asking respondents to state their perception of the importance of each crop to the household in terms of food security and income-we can disaggregate responses by gender of the household head $(67 \%$ male and 33\% female in the sample), but also by gender of the survey respondent (41\% male and 59\% female in the sample, with $41 \%$ of male-headed households represented in the survey by a female respondent). While the former allows us to examine differences in gendered preferences around crops at the household level (Figures 5A and 5C), the latter provides insights into individual preferences by respondent gender (Figures 5B and 5D).

Two key findings emerge from these summary responses. First, we see relatively few statistically significant differences in food security importance scores or income importance scores when splitting responses by gender of the household head (Figure $5 \mathrm{~A}$ and $5 \mathrm{C}$ ). However, the pattern is broadly consistent with expectations: female-headed households appear to emphasize the food security value of crops more than male-headed, and male-headed households are more likely to emphasize income importance of the crops than female-headed households. With limited exceptions, however, female-headed and male-headed households appear to exhibit similar attitudes around the relative importance of different crops for food and income security.

Second, however, we also find that estimates of perceptions of the importance of crops for food and income security appear to depend, at least in part, on how gender is analyzed (gender of the bousehold head, or gender of the respondent). When dividing the same survey responses by gender of 


\section{Figure 5. Importance of Different Crops for Household Food Security and Incomes, by Gender of the Household Head and by Gender of the Survey Respondent}

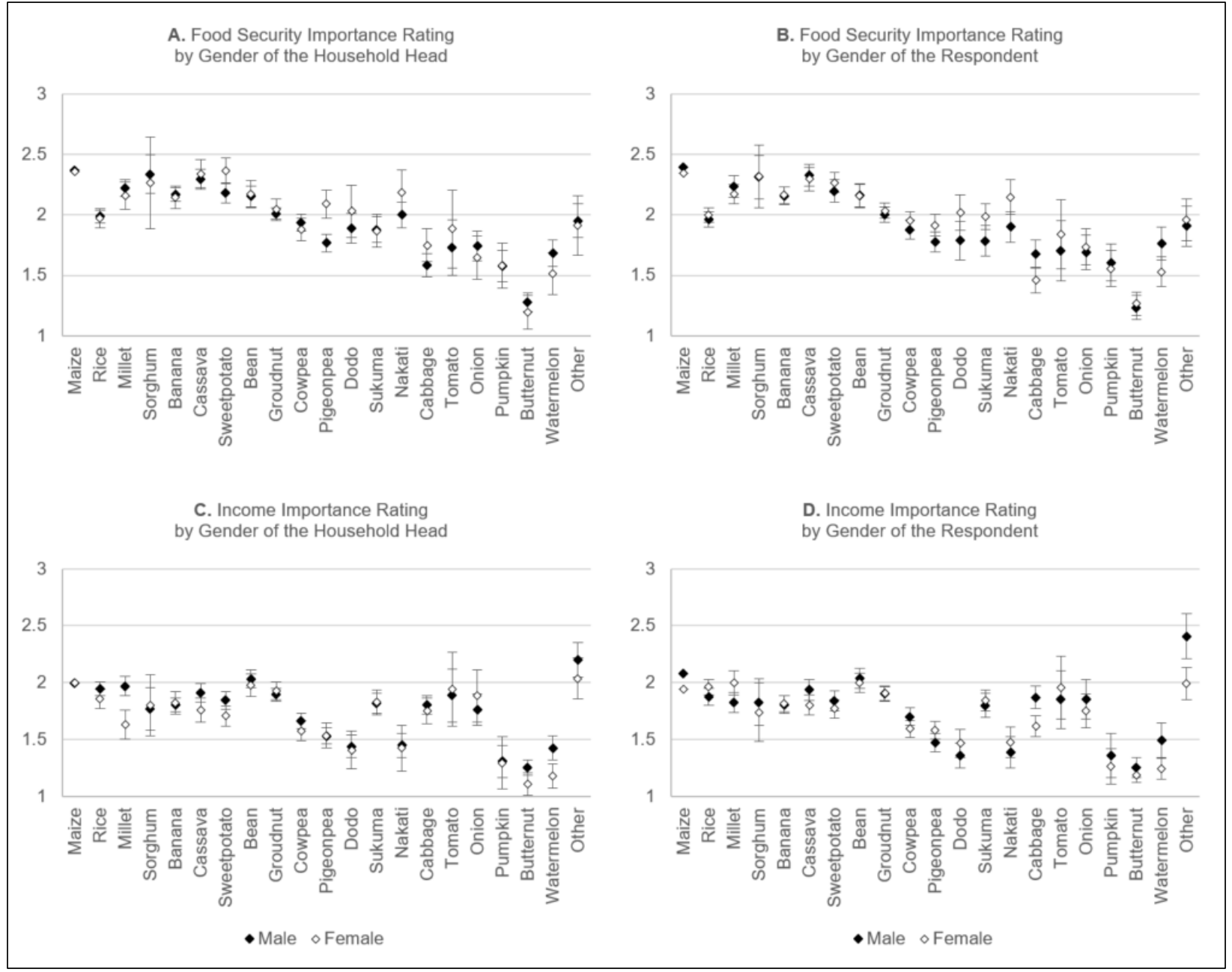

the survey respondent (Figure 5B and 5D), several more significant differences in responses emerge. Women assign higher food security importance than men for a range of traditional food crops, including cowpea, pigeonpea, dodo, sukuma wiki, and nakati, and less food security importance than men for cash crops like cabbage and watermelon. Country-specific findings (shown in Appendix A) reveal even more striking differences-suggesting that women in female-headed households may see certain crops as food security crops, while women in male-headed households are more likely to see them as income-generating crops.

When comparing responses to the question about the importance of each crop for household income, contrary to expectations that gender norms might lead male-headed households to assign a higher value to the income potential of different crops, we see relatively few significant differences in terms of income importance ratings given to crops by female- versus male-headed households. However, considering the gender of respondents rather than the gender of household heads, women respondents in the sample on average see less income value in a range of crops than men, including maize, cabbage, watermelon, and other crops-perhaps reflecting gendered differences in access to the income from commercialization of these crops among women in male-headed households. Country-specific results in Appendix A again show that the way gender is captured-either looking at the gender of the household head or the 
gender of the individual respondent—has important implications for which crops appear most important for food and income security among women smallholders.

\section{Discussion}

This study draws on a detailed original dataset applying an identical survey instrument across rural communities in three countries to explore how the gender composition of smallholder households in East Africa relates to their cropping choices. Building on many previous studies of gender and smallholder decision-making using a range of methods in a variety of contexts (Amri \& Kimaro, 2010; Anderson et al., 2017; Bentley et al., 2017; Fisher \& Carr, 2015; Me-Nsope \& Larkins, 2016; Nuijten, 2010; Pincus et al., 2018; Teeken et al., 2018), our analysis provides two key findings: female-headed households that generally have less access to land and other resources are more likely to diversify their food crop production than male-headed households, and that gender must be considered alongside other variables such as country context and socioeconomic status to more comprehensively understand decisions around crop cultivation.

Results from this analysis of cropping patterns and preferences among female- and male-headed households in Kenya, Tanzania, and Uganda suggest that while female-headed households grow fewer crops overall than male-headed households, the story is more complex after accounting for crop type (food versus income) alongside land resource constraints that disproportionately affect female-headed households. Consistent with previous literature (Teeken et al., 2018; Tobin, Jones, \& Thiede, 2019; Waldman et al., 2016), crop choices generally reflect regional crop preferences, likely resulting from a combination of agroecological suitability, cultural preferences, market access, and/or local demand, shaping the common agricultural practices among smallholders in the study countries. However, we also see significant differences in crop choices according to the gender of the household head. In addition to the general trend of male-headed households cultivating more crops overall, we see a higher percentage of maleheaded households cultivating both crops that are generally used for home consumption (cowpea and banana in Kenya, sorghum and sweet potato in Tanzania, rice and cowpea in Uganda), as well as market-oriented crops where for most crop categories male-headed households are more likely to be producers of crops for market sale. While the tendency for male-headed households to produce more commercially-oriented crops is expected based on previous findings (Bentley et al., 2017; Christinck et al., 2017; Mudege \& Walsh, 2016), they also produce subsistence crops at higher frequencies in our sample, which appears to contrast with the notion that female-headed households more commonly emphasize crops for home consumption (Pincus et al., 2018).

Furthermore, despite the general global trend of women being important keepers of agrobiodiversity (Howard, 2003; Zimmerer et al., 2015), our findings suggest that male-headed households are significantly more likely to grow a larger variety of crops. We hypothesize- though cannot test with these data - that male-headed households' production of both subsistence crops and more diverse crop portfolios at higher rates than femaleheaded households may in part be a reflection of both resource access as well as intra-household dynamics in which women who reside in maleheaded households are also exerting some decision-making power over cropping choices (or, in other cases, in which women in male-headed households are expected to grow "women's crops" to meet family needs). In other words, the relatively greater diversity of crop portfolios in maleheaded households may reflect a combination of male-headed households' historically greater resource and market access as well as both men's and women's crop preferences.

These findings become even more nuanced when we consider female- versus male-headed households' relative access to key productive resources like land. Multivariate regression results suggest female-headed households grow more HDDS food groups per unit of land available than their male-headed household counterparts. Past research suggests that when faced with resource constraints, female-headed households may be more likely to utilize crop diversity as a strategy to meet livelihood needs (FAO, 2019; Quisumbing et 
al., 2014). This pattern is reflected in our findings, which suggest in the face of limited market access and disproportionate land resource constraints, female-headed households emphasize food crops for home consumption, and plant more diverse portfolios of food crops, compared to male-headed ones (Pincus et al., 2018; Tavenner et al., 2019). Though our findings do not allow for deeper explanations of whether food crop diversification among female-headed households occurs out of necessity due to resource barriers or because of a greater valuation of agrobiodiversity, we provide some preliminary evidence that women farmerswhether in female-headed or male-headed households-do place a greater value on the food security importance of crops, and less on the income importance, than their male counterparts in Kenya, Tanzania, and Uganda.

Situating these findings within the context of current research, policies, and programs advocating market-oriented development approaches in subSaharan Africa, our study joins others who have called for caution in assuming that a focus on more market opportunities will necessarily spur improvements in wellbeing among female-headed smallholder households. The findings in this study suggest that female-headed households who are constrained in their land access are more likely to use alternative strategies like crop diversification for home consumption rather than crop specialization for market sale. If they do not have the resources, including sufficient land to meet the demands of newly accessible markets, then growing markets may do little to benefit many female-headed households. Following the insights of previous work (Peterman et al., 2011; Quisumbing et al., 2014), our study contributes to the growing evidence base that alleviating gendered barriers to access to resources such as land may be a necessary prerequisite to the success of development interventions pursuing market-oriented approaches.

Importantly, however, our findings are also in line with previous research emphasizing that gender constitutes just one of the many factors intersecting to explain varying outcomes among smallholders (Gengenbach et al., 2018; Loconto, 2015; Quisumbing et al., 2014). When considering correlates of on-farm crop diversity (number of
HDDS food groups grown) while controlling for gender and land availability, we find household heads' age, educational status, off-farm income sources, and social networks are all significant predictors. Younger households and those with low educational status might grow a more diverse range of crops because few other options exist, while households with an array of income sources, higher educational status, and more social ties may grow multiple crops to diversify further their portfolio of livelihood activities. As previous scholarship suggests, though critically important, gender is but one among many factors that shape how rural smallholder households structure their livelihoods (Gengenbach et al., 2018; Rubin \& Manfre, 2014).

\section{Conclusion}

The crop portfolios of female-headed households have been linked to higher dietary diversity within households (Jones et al., 2014) as well as to the conservation of agrobiodiversity (Zimmerer et al., 2015); there are thus important reasons to understand gendered differences in crop preferences and how different constraints affect female- and maleheaded households in low-income countries. Our findings echo the results of previous studies showing significant gendered differences in crop choices and resource access across multiple contexts in sub-Saharan Africa; the findings presented here also raise questions for future research as marketoriented rural development efforts continue across the region. Consistent with previous studies, our findings suggest that male-headed households have greater access to land for crop cultivation, and also tend towards income-oriented crops more than female-headed households (Bentley et al., 2017; Christinck et al., 2017; Mudege \& Walsh, 2016). On the one hand, this may lend support to widely held perspectives that more market opportunities for female-headed households are needed, but on the other hand, these findings may also suggest the gender dynamics that occur as rural agrarian communities shift from a focus on crops for home consumption to more market sales must be carefully monitored. Indeed, as Tavenner et al. (2019) find, the historical patterns and current social norms providing men greater access to input and output markets for commercial crop cultivation 
may actually lead to worsening gender inequality in rural communities as crop commercialization expands. Our findings also align with previous evidence that resource-constrained female-headed smallholder households emphasize crops for home consumption more than male-headed households (Pincus et al., 2018). An understudied but important area for future research is the underlying values driving men's and women's choices around crop production. One hypothesis is that with equal opportunities, women's choices would align with men's - in other words, that all smallholders would pursue increased production of market-oriented crops and increased commercialization if they could. A more critical line of inquiry, however, might question whether women's tendency to produce crops for home consumption is in part due to valuing a diverse crop portfolio that provides for home consumption and conserves locallypreferred crop varieties. As further studies of these important questions are pursued, there will be a need to consider multiple explanatory factors in addition to gender (e.g., access to resources, income, agroecological context, cultural norms), as well as to assess gender dynamics within households (e.g., preferences and constraints of wives versus husbands), in order to understand how agricultural policies and rural development programs may affect women and men farmers.

\section{References}

Alliance for a Green Revolution [AGRA]. (2017). AGRA annual progress report 2007-2016. Retrieved from https://agra.org/

Ampaire, E. L., Acosta, M., Huyer, S., Kigonya, R., Muchunguzi, P., Muna, R., \& Jassogne, L. (2020). Gender in climate change, agriculture, and natural resource policies: Insights from East Africa. Climatic Change, 158, 43-60. https://doi.org/10.1007/s10584-019-02447-0

Amri, E., \& Kimaro, C. (2010). The role of gender in management and conservation of seed diversity of crops and varieties: A case study in Bariadi, Tanzania. American-Eurasian Journal of Agricultural and Environmental Science, 8(4), 365-369. Retrieved from https://www.idosi.org/aejaes/online.htm

Anderson, C. L., Reynolds, T. W., \& Gugerty, M. K. (2017). Husband and wife perspectives on farm household decision-making authority and evidence on intra-household accord in rural Tanzania. World Development, 90, 169183. https://doi.org/10.1016/j.worlddev.2016.09.005

Andersson, K., Lodin, J. B., \& Chiwona-Karltun, L. (2016). Gender dynamics in cassava leaves value chains: The case of Tanzania. Journal of Gender, Agriculture and Food Security, 1(2), 84-109. https://doi.org/10.19268/JGAFS.122016.5

Bentley, J. W., Olanrewaju, A. S., Madu, T., Olaosebikan, O., Abdoulaye, T., Assfaw Wossen, T., Manyong, V. M., Kulakow, P. A., Ayedun, B., Ojide, M., Girma Tessema, G., Rabbi, I. Y., Asumugha, G. N., \& Tokula, M. (2017). Cassava farmers' preferences for varieties and seed dissemination system in Nigeria: Gender and regional perspectives. IITA monograph, Ibadan, Nigeria: IITA. https://cgspace.cgiar.org/handle/10568/80554

Carr, E. R., \& Thompson, M. C. (2014). Gender and climate change adaptation in agrarian settings: Current thinking, new directions, and research frontiers. Geography Compass, 8(3), 182-197. https://doi.org/10.1111/gec3.12121

Christinck, A., Weltzien, E., Rattunde, F., \& Ashby, J. (2017). Gender differentiation of farmer preferences for varietal traits in crop improvement: Evidence and issues (Working Paper No. 2). Retrieved from CGIAR Gender and Agriculture Research Network website: https://cgspace.cgiar.org/handle/10947/4660

Doss, C., Kovarik C., Peterman, A., Quisumbing, A., \& van den Bold, M. (2015). Gender inequalities in ownership and control of land in Africa: Myth and reality. Agricultural Economics, 46(3), 403-434. https://doi.org/10.1111/agec.12171

Doss, C., Meinzen-Dick, R., Quisumbing, A., \& Theis, S. (2018). Women in agriculture: Four myths. Global Food Security, 16, 69-74. https://doi.org/10.1016/j.gfs.2017.10.001

Fisher, M., \& Carr, E. R. (2015). The influence of gendered roles and responsibilities on the adoption of technologies that mitigate drought risk: The case of drought-tolerant maize seed in eastern Uganda. Global Environmental Change, 35, 82-92. https://doi.org/10.1016/j.gloenvcha.2015.08.009 
Food and Agriculture Organization of the United Nations (FAO). (2019). Sex-disaggregated data in agriculture and sustainable resource management: New approaches for data collection and analysis. Rome: FAO.

http://www.fao.org/publications/card/en/c/I8930EN

FAO, International Fund for Agricultural Development (IFAD), UNICEF, WFP (World Food Program), \& World Health Organization (WHO). (2019). The state of food security and nutrition in the world: Safeguarding against economic slowdowns and downturns. Retrieved from the FAO website: http://www.fao.org/publications/sofi/en/

Gengenbach, H., Schurman, R. A., Bassett, T. J., Munro, W. A., \& Moseley, W. G. (2018). Limits of the New Green Revolution for Africa: Reconceptualising gendered agricultural value chains. Geographical Journal, 184(2), 208-214. https://doi.org/10.1111/geoj.12233

Hadley, C., Belachew, T., Lindstrom, D., \& Tessema, F. (2011). The shape of things to come? Household dependency ratio and adolescent nutritional status in rural and urban Ethiopia. American Journal of Physical Anthropology, 144(4), 643-652. https://doi.org/10.1002/ajpa.21463

Hellin, J., Lundy, M., \& Meijer, M. (2009). Farmer organization, collective action and market access in Meso-America. Food Policy, 34(1), 16-22. https://doi.org/10.1016/j.foodpol.2008.10.003

Horton, D. (2008). Facilitating pro-poor market chain innovation: An assessment of the participatory market chain approach in Uganda. Lima, Peru: International Potato Center.

Horton, D., Akello, B., Aliguma, L., Bernet, T., Devaux, A., Lemaga, B., Magala, D., Mayanja, S., Sekitto, I., Thiele, G., \& Velasco, C. (2010). Developing capacity for agricultural market chain innovation: Experience with 'PCMA' in Uganda. Journal of International Development, 22(3), 367-389. https://doi.org/10.1002/jid.1694

Howard, P. L. (2003). Women and the plant world: An exploration. P. L. Howard (Ed.), Women and plants: Gender relationships in biodiversity management and conservation (pp. 1-48). London: Zed Books.

International Fund for Agricultural Development (IFAD). (2016). Rural development report 2016: Fostering inclusive rural transformation. Retrieved from IFAD website: https://www.ifad.org/en/web/knowledge/publication/asset/39240288

Jones, A. D., Shrinivas, A., \& Bezner-Kerr, R. (2014). Farm production diversity is associated with greater household dietary diversity in Malawi: Findings from nationally representative data. Food Policy, 46, 1-12. https://doi.org/10.1016/j.foodpol.2014.02.001

Jost, C., Kyazze, F., Naab, J., Neelormi, S., Kinyangi, J., Zougmore, R., \& Kristjanson, P. (2016) Understanding gender dimensions of agriculture and climate change in smallholder farming communities. Climate and Development, 8(2), 133-144. https://doi.org/10.1080/17565529.2015.1050978

Kaplinsky, R. (2000). Globalisation and unequalisation: What can be learned from value chain analysis. Journal of Development Studies, 37(2), 117-146. https://doi.org/10.1080/713600071

Kennedy, G., Ballard, T., \& Dop, M. (2011). Guidelines for measuring household and individual dietary diversity. Retrieved from FAO website: http://www.fao.org/home/en/

Koppmair, S., Kassie, M., \& Qaim, M. (2017). Farm production, market access and dietary diversity in Malawi. Public Health Nutrition, 20(2), 325-335. https://doi.org/10.1017/S1368980016002135

Larson, J. B., Castellanos, P., \& Jensen, L. (2019). Gender, household food security, and dietary diversity in western Honduras. Global Food Security, 20, 170-179. https://doi.org/10.1016/j.gfs.2019.01.005

Loconto, A. (2015). Can certified-tea value chains deliver gender equality in Tanzania? Feminist Economics, 21(3), 191-215. https://doi.org/10.1080/13545701.2014.1001765

Malapit, H. J., Kovarik, C., Sproule, K., Meinzen-Dick, R. S., \& Quisumbing, A. R. (2015). Instructional guide on the abbreviated women's empowerment in agriculture index ( $A$-WE $A I)$. Retrieved from the International Food Policy Research Institute website: http://www.ifpri.org/publication/instructional-guide-abbreviated-womens-empowermentagriculture-index-weai

Malapit, H. J .L., \& Quisumbing, A. R. (2015). What dimensions of women's empowerment in agriculture matter for nutrition in Ghana? Food Policy, 52, 54-63. https://doi.org/10.1016/i.foodpol.2015.02.003

Meemken, E.-M., \& Qaim, M. (2018). Can private food standards promote gender equality in the small farm sector? Journal of Rural Studies, 58, 39-51. https://doi.org/10.1016/i.jrurstud.2017.12.030 
Me-Nsope, N., \& Larkins, M. (2016). Beyond crop production: Gender relations along the pigeon pea value chain and implications for income and food security in Malawi. Journal of Gender, Agriculture and Food Security, 1(3), 1-22. https://doi.org/10.19268/JGAFS.132016.1

Mudege, N. N., \& Walsh, S. (2016). Gender and roots tubers and bananas seed systems: A literature review (Working Paper No. 2016-2). Lima, Peru: CGIAR Research Program on Roots, Tubers, and Bananas (RTB).

Nakazi, F., Njuki, J., Ugen, M. A., Aseete, P., Katungi, E., Birachi, E., Kabanyoro, R., Mugagga, I. J., \& Nanyonjo, G. (2017). Is bean really a women's crop? Men and women's participation in bean production in Uganda. Agriculture and Food Security, 6, 22. https://doi.org/10.1186/s40066-017-0102-z

Niles, M. T., \& Salerno, J. D. (2018). A cross-country analysis of climate shocks on smallholder food insecurity. PLOS ONE, 13(2). https://doi.org/10.1371/journal.pone.0192928

Nuijten, E. (2010). Gender and management of crop diversity in The Gambia. Journal of Political Ecology, 17(1), $42-58$. https://doi.org/10.2458/v17i1.21698

Perez, C., Jones, E. M., Kristjanson, P., Cramer, L., Thornton, P. K., Förch, W., \& Barahona, C. (2015) How resilient are farming households and communities to a changing climate in Africa? A gender-based perspective. Global Environmental Change, 34, 95-107. https://doi.org/10.1016/j.gloenvcha.2015.06.003

Peterman, A., Quisumbing, A., Berhman, J., \& Nkonya, E. (2011). Understanding the complexities surrounding gender differences in agricultural productivity in Nigeria and Uganda. The Journal of Development Studies, 47(10), $1482-1509$. https://doi.org/10.1080/00220388.2010.536222

Pincus, L., Croft, M., Roothaert, R., \& Dubois, T. (2018). African indigenous vegetable seed systems in western Kenya. Economy Botany, 72(4), 380-395. https://doi.org/10.1007/s12231-018-9440-4

Pingali, P. (2015). Agricultural policy and nutrition outcomes-Getting beyond the preoccupation with staple grains. Food Security, 7(3), 583-591. https://doi.org/10.1007/s12571-015-0461-x

Quisumbing, A. R., Meinzen-Dick, R., Raney, T. L., Croppenstedt, A., Behrman, J. A., \& Peterman, A. (2014). Gender in agriculture: Closing the knowledge gap. Dordrecht: Springer. https://doi.org/10.1007/978-94-017-8616-4

Rubin, D., \& Manfre, C. (2014). Promoting gender-equitable agricultural value chains: Issues, opportunities, and next steps. In A. R. Quisumbing, R. Meinzen-Dick, T. L. Raney, A. Croppenstedt, J. A. Behrman, and A. Peterman (Eds.), Gender in Agriculture (pp. 287-313). Dordrecht: Springer. https://doi.org/10.1007/978-94-017-8616-4_12

Singh, S. (2007). Deconstructing 'gender and development' for 'identities of women.' International Journal of Social Welfare, 16(2), 100-109. https://doi.org/10.1111/j.1468-2397.2006.00454.x

Sudman, S., \& Kalton, G. (1986). New developments in the sampling of special populations. Annual Review of Sociology, 12(1), 401-429. https://doi.org/10.1146/annurev.so.12.080186.002153

Tavenner, K., van Wijk, M., Fraval, S., Hammond, J., Baltenweck, I., Teufel, N., Kihoro, E., de Haan, N., van Etten, J., Steinke, J., Baines, D., Carpena, P., Skirrow, T., Rosenstock, T., Lamanna, C., Ng’endo, M., Chesterman, S., Namoi, N., \& Manda, L. (2019). Intensifying inequality? Gendered trends in commercializing and diversifying smallholder farming systems in east Africa. Frontiers in Sustainable Food Systems. https://doi.org/10.3389/fsufs.2019.00010

Teeken, B., Olaosebikan, O., Haleegoah, J., Oladejo, E., Madu, T., Bellow, A., Parkes, E., Egesi, C., Kulakow, P., Kirscht, H., \& Tufan, H. A. (2018). Cassava trait preferences of men and women farmers in Nigeria: Implications for breeding. Economic Botany, 72(3), 263-277. https://doi.org/10.1007/s12231-018-9421-7

The Economist Intelligence Unit. (2018). Global food security index 2018: Building resilience in the face of risking food-security risks. Retrieved from The Economist Group website: https://foodsecurityindex.eiu.com

Tobin, D., Jones, K., \& Thiede, B. C. (2019). Does crop diversity at the village level influence child nutrition security? Evidence from 11 sub-Saharan African countries. Population and Environment, 41(2), 74-97. https://doi.org/10.1007/s11111-019-00327-4

Toenniessen, G., Adesina, A., \& DeVries, J. (2008). Building an Alliance for a Green Revolution in Africa. Annals of the New York Academy of Sciences, 1136(1), 233-242. https://doi.org/10.1196/annals.1425.028

Waldman, K. B., Ortega, D. L., Richardson, R. B., Clay, D. C., \& Snapp, S. (2016). Preferences for legume attributes in maize-legume cropping systems in Malawi. Food Security, 8(6), 1087-1099. https://doi.org/10.1007/s12571-016-0616-4 
Wooten, S. (2003). Losing ground: Gender relations, commercial horticulture, and threats to local plant diversity in rural Mali. In P. L. Howard (Ed.), Women and plants: Gender relations in biodiversity management and conservation (pp. 229-242). London: Zed Books.

Zimmerer, K. S., Carney, J. A., \& Vanek, S. J. (2015). Sustainable smallholder intensification in global change? Pivotal spatial interactions, gendered livelihoods, and agrobiodiversity. Current Opinion in Environmental Sustainability, 14, 49-60. https://doi.org/10.1016/j.cosust.2015.03.004 


\section{Appendix A1. Crop Importance for Food Security (Low, Medium, High) by Country and Gender of the Household Head}

Kenya

0\% $20 \% \quad 40 \% \quad 60 \% \quad 80 \% 100 \%$

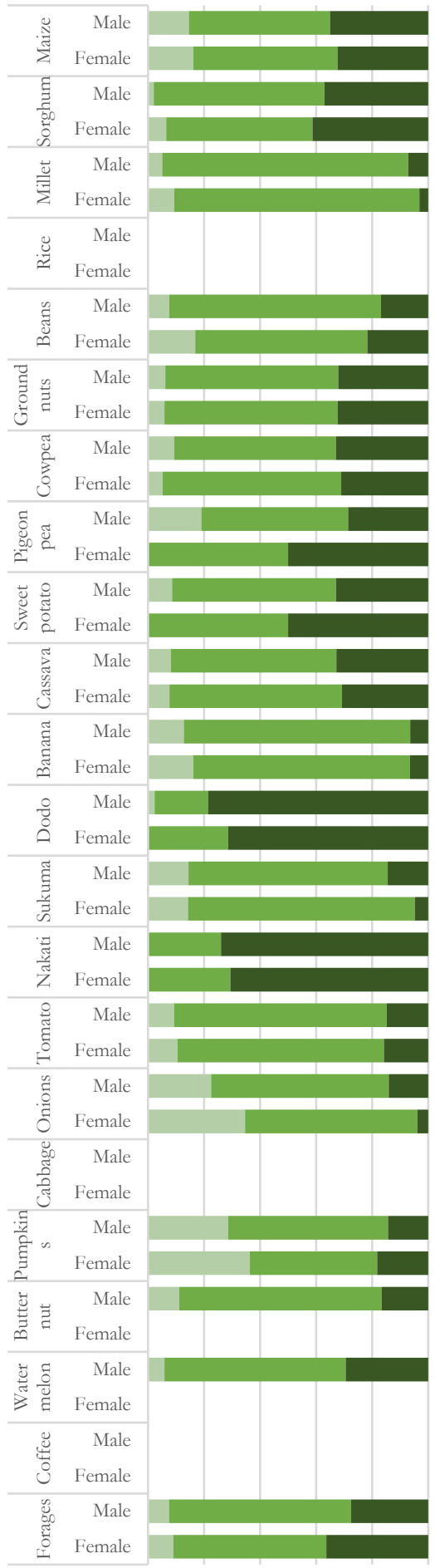

Tanzania

$0 \% \quad 20 \% \quad 40 \% \quad 60 \% \quad 80 \% 100 \%$

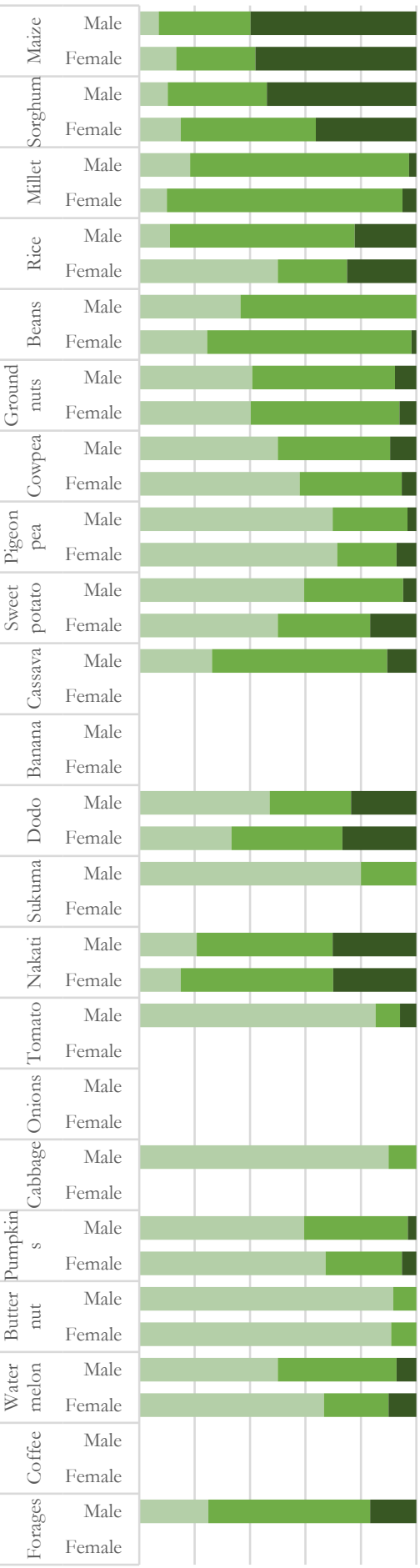

Low nedium $\mathbf{n}$ High
Uganda

0\% 20\% 40\% 60\% 80\% $100 \%$

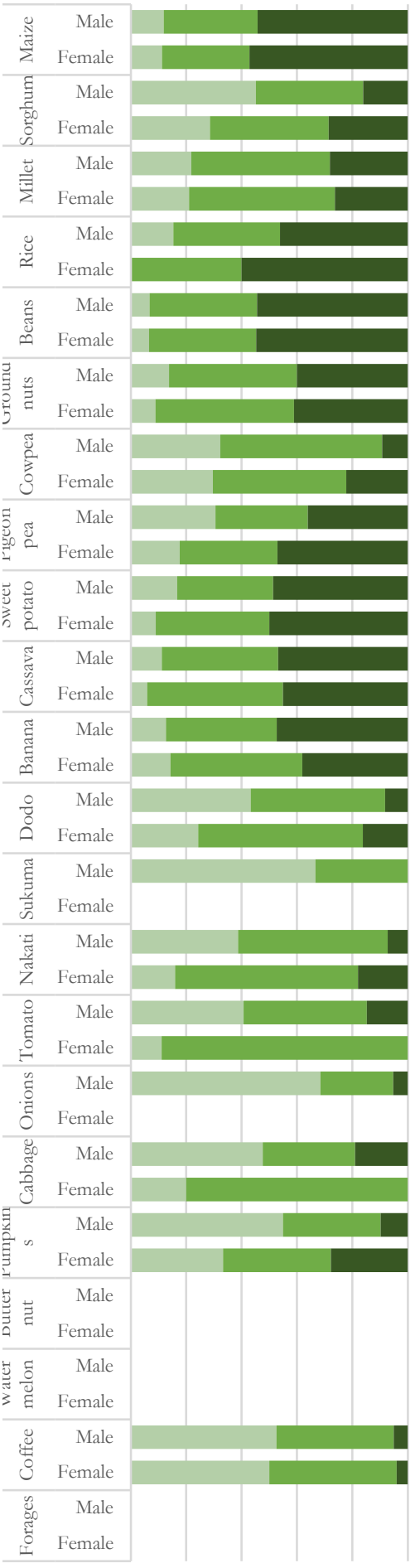




\section{Appendix A2. Crop Importance for Food Security (Low, Medium, High) by Country and Gender of the Survey Respondent}

Kenya

$\begin{array}{lll}0 \% & 20 \% \quad 40 \% \quad 60 \% \quad 80 \% 100 \%\end{array}$

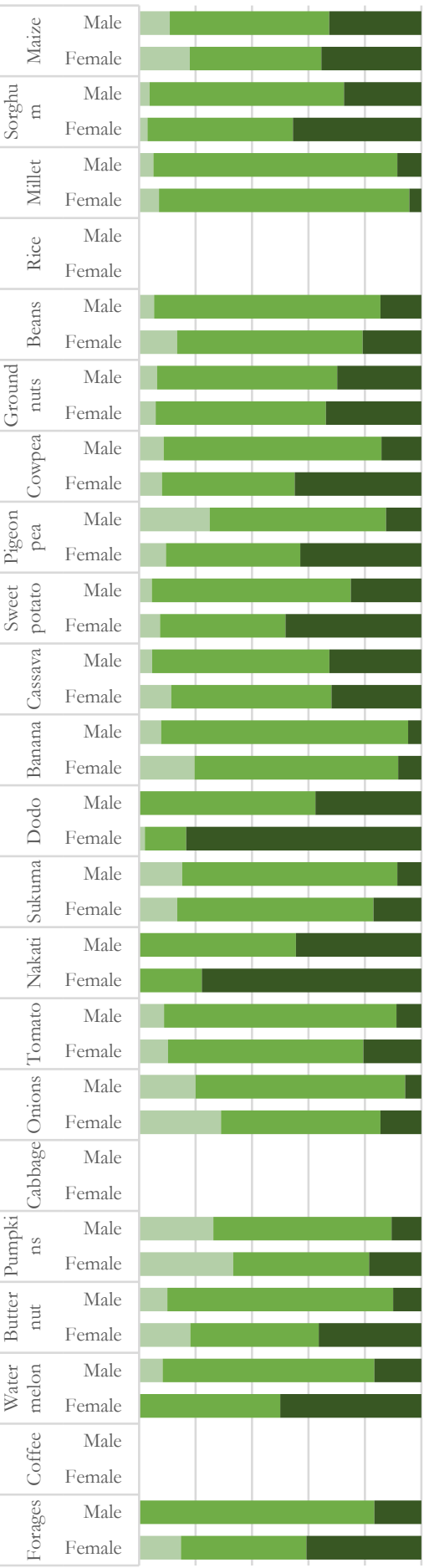

Tanzania

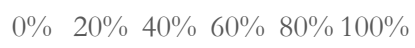

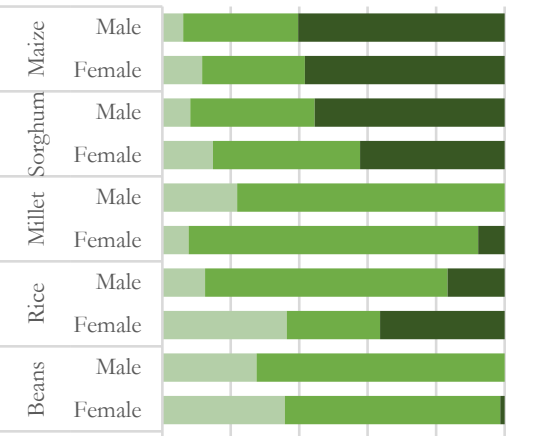

$\bar{\Xi}$

a

ङे Female

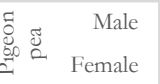

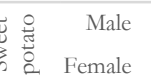

Male

约 Female

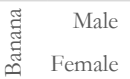

응 Male

A Female

还 Male

की Female

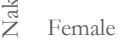

ัํ Male

है Female

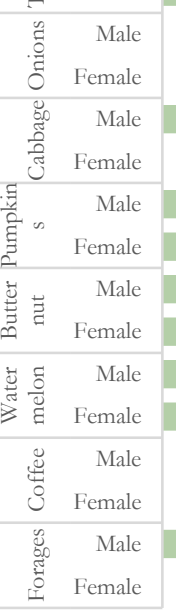
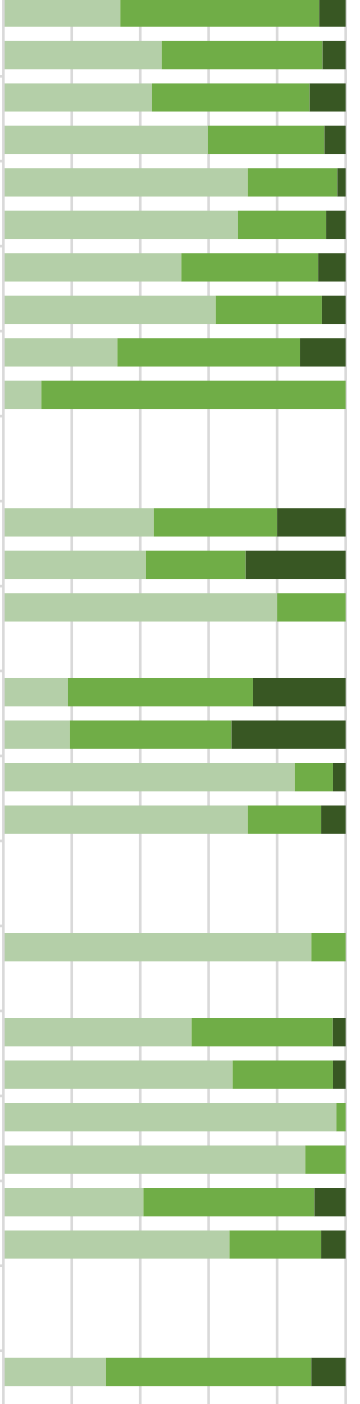

Low $\square$ Medium $\square$ High
Uganda

0\% $20 \% \quad 40 \% \quad 60 \% \quad 80 \% 100 \%$
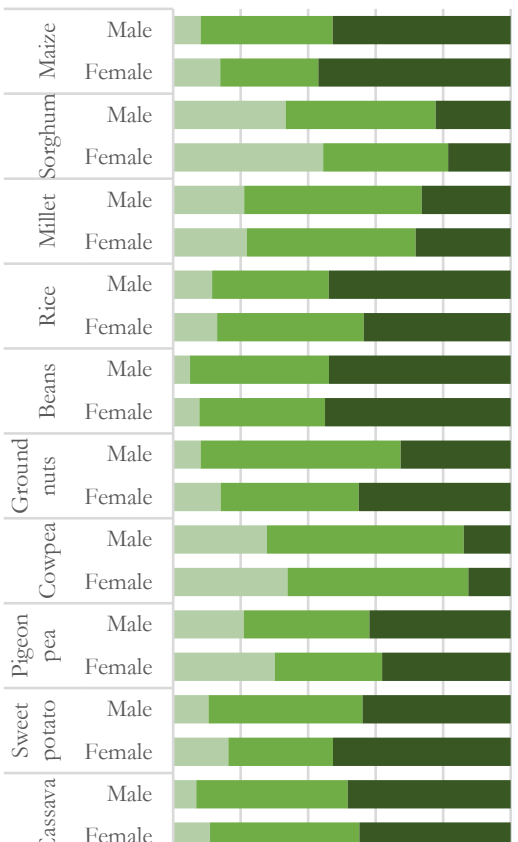

Female
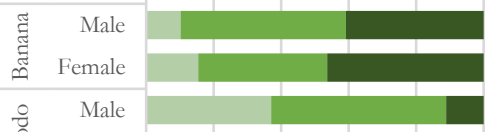

$\stackrel{\circ}{\circ}$ Female

芩 Male

Female

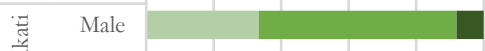

乙̌ Female

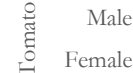

: Male

$\begin{array}{lr}\text { ठิ } & \text { Female } \\ \text { \&o } & \text { Male }\end{array}$

हैं Female
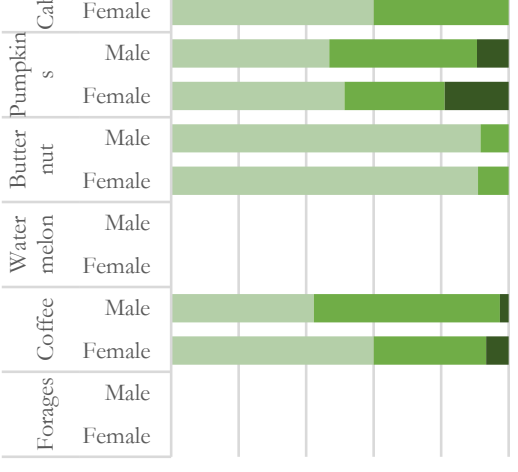


\section{Appendix A3. Crop Importance for Income (Low, Medium, High) by Country and Gender of the Household Head}

Kenya

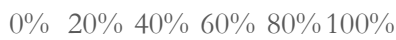

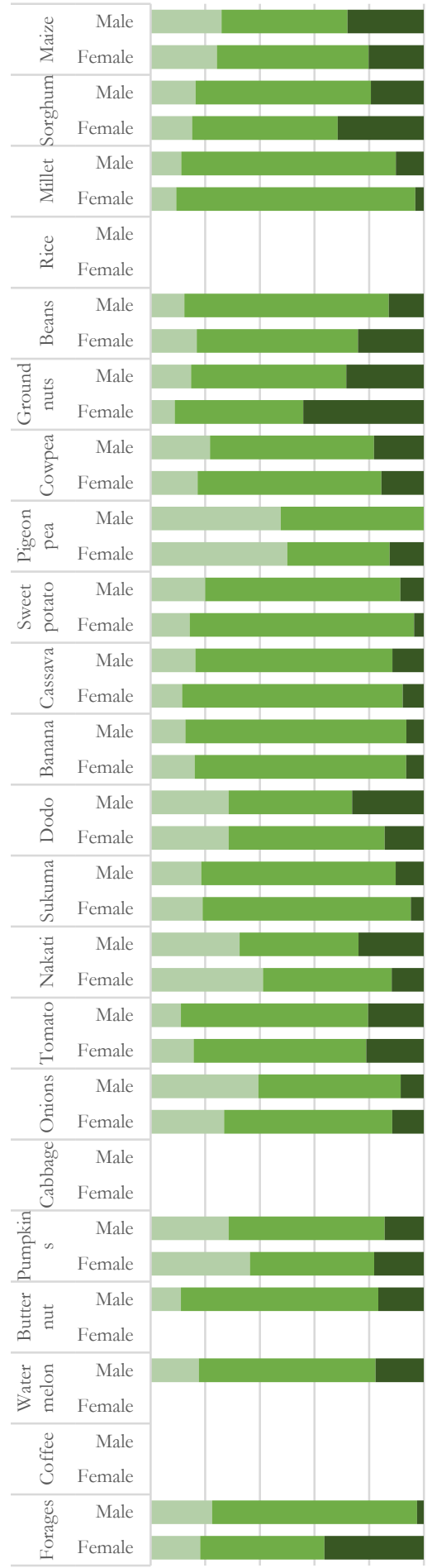

Tanzania

0\% 20\% 40\% $60 \% \quad 80 \% 100 \%$$$
\text { 要 }
$$

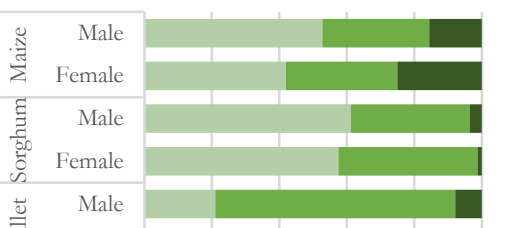

竞

Female

Female

总

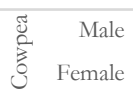

Male

Female

造 Male

‥ Female

Male

Female

气 $\mathrm{Mal}$

¿ Male

ค Female

墨 $\begin{array}{r}\text { Male } \\ \text { Female }\end{array}$

Male

$\therefore \quad$ Male

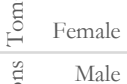

Female

傿 Male

डै Female

碽的 $\begin{array}{r}\text { Male } \\ \text { Female }\end{array}$

苞 Male

F Female

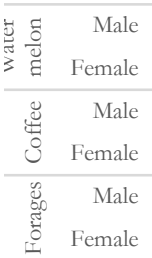

n Low $\square$ Medium
Uganda

0\% 20\% 40\% 60\% 80\% 100\%

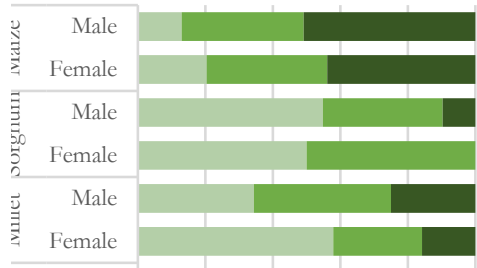

Male

Male

Female

Male

Male

Female

Male

. Female

Male

$\stackrel{2}{2}$ Female

Male

Female

Male

Female

Male

Female

Male

Female

Male

Female

Male

Female

ค Male

Female

Male

Female

Male

Female

Male

\begin{tabular}{rr}
\hline & Male \\
& Female
\end{tabular}

บ Male

Female

Male

Female
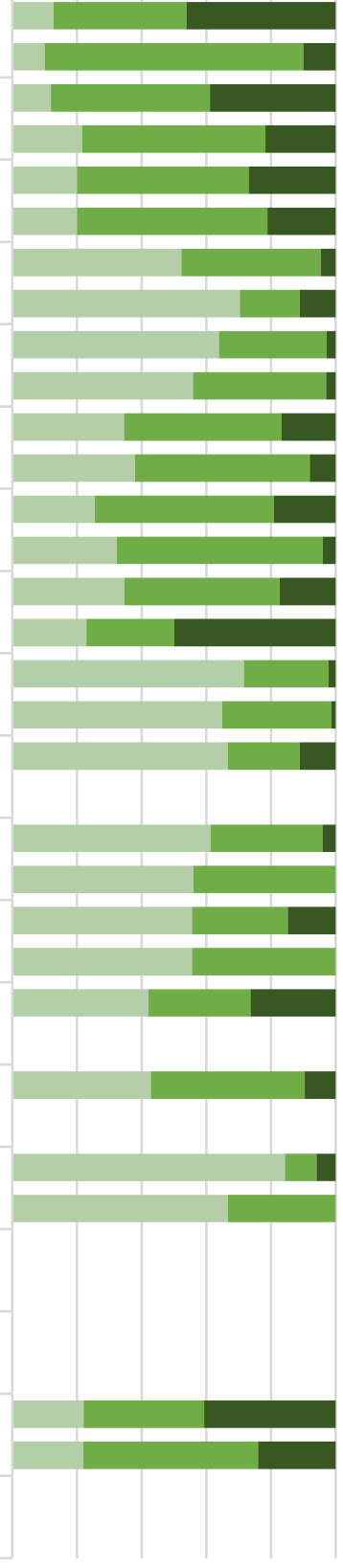


\section{Appendix A4. Crop Importance for Income (Low, Medium, High) by Country and Gender of the Survey Respondent}

Kenya

0\% $20 \% \quad 40 \% \quad 60 \% \quad 80 \% 100 \%$

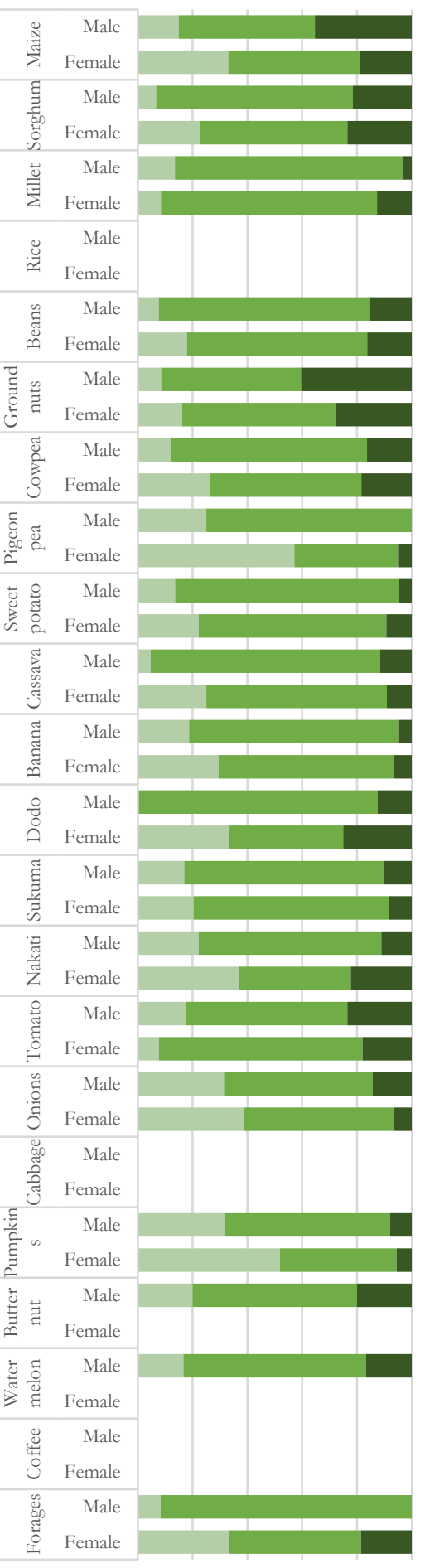

Tanzania

0\% $20 \% 40 \% \quad 60 \% \quad 80 \% 100 \%$
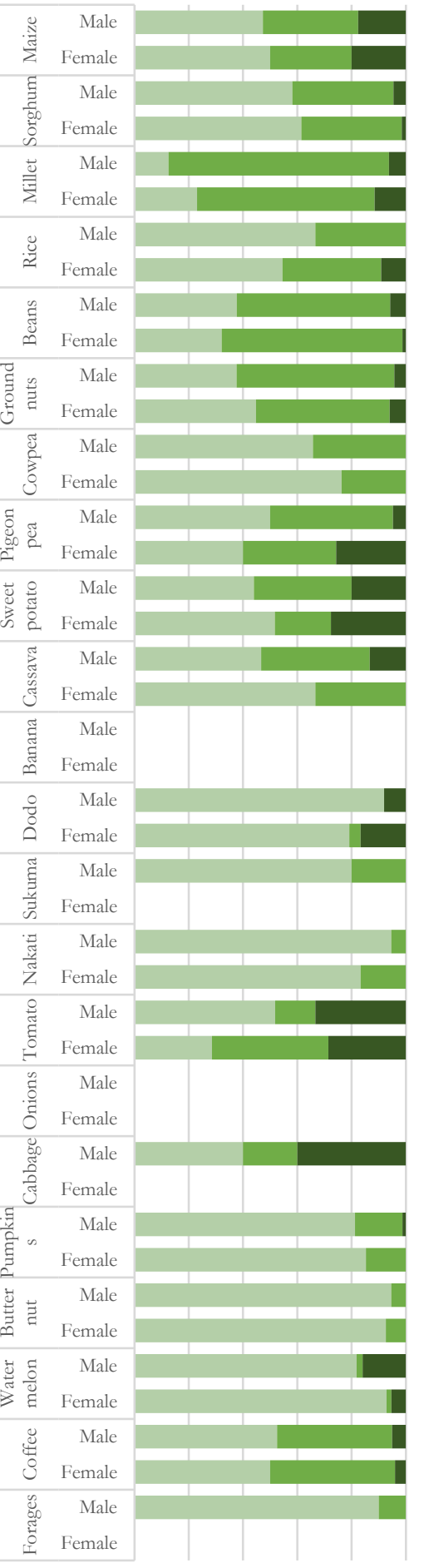

(1)
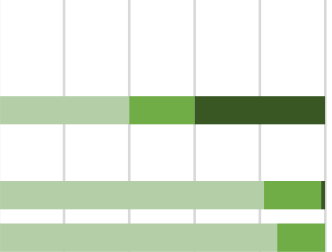

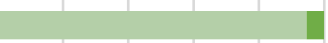
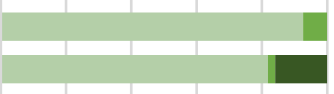

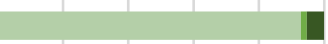

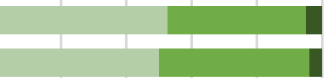

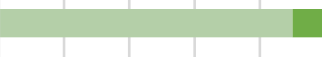

Low Medium $\mathbf{n i g h}$
Uganda

$0 \% \quad 50 \% \quad 100 \%$
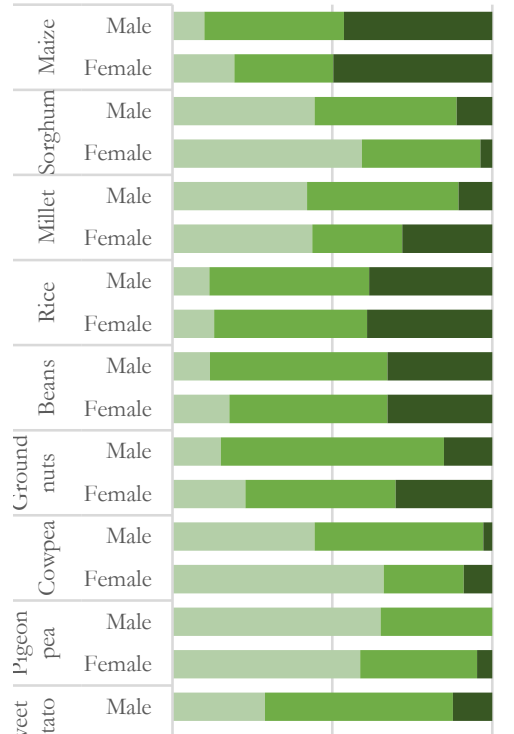

$\circ$

¿. Female

Male

ป Female

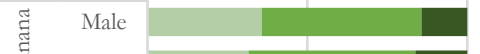

๓ Female

i Male

Female

芩 Male

क Female

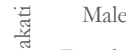

Z Female

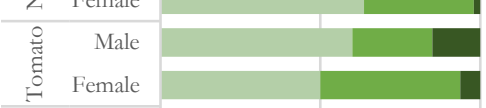

H Female

: ${ }_{0}^{\circ}$ Female

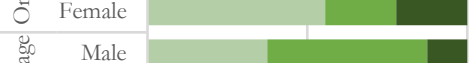

ज़ Female

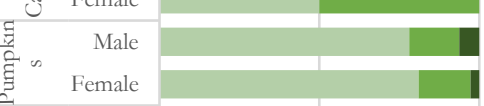

2

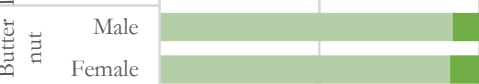

홍 Male

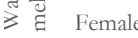

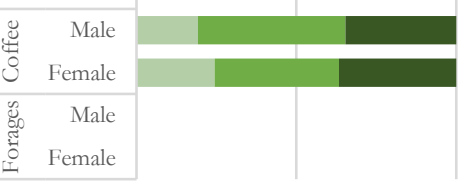

